\title{
Neuroprotective Action of Multitarget 7-Aminophenanthridin- 6(5H)-one Derivatives against Metal-Induced Cell Death and Oxidative Stress in SN56 Cells
}

Paula Moyano," David Vicente-Zurdo," Cristina Blázquez-Barbadillo, J. Carlos Menéndez, Juan F. González,* Noelia Rosales-Conrado,* and Javier del Pino*

Cite This: ACS Chem. Neurosci. 2021, 12, 3358-3372

Read Online

ABSTRACT: Neurodegenerative diseases have been associated with brain metal accumulation, which produces oxidative stress (OS), matrix metalloproteinases (MMPs) induction, and neuronal cell death. Several metals have been reported to downregulate both the nuclear factor erythroid 2-related factor $2(\mathrm{Nrf} 2)$ pathway and the antioxidant enzymes regulated by it, mediating OS induction and neurodegeneration. Among a recently discovered family of multitarget 7-amino-phenanthridin-6-one derivatives (APH) the most promising compounds were tested against metal-induced cell death and OS in SN56 cells. These compounds, designed to have chelating activity, are known to inhibit some MMPs and to present antioxidant and neuroprotective effects against hydrogen peroxide treatment to SN56 neuronal cells. However, the mechanisms that mediate this protective effect are not fully understood. The obtained results show that compounds APH1, APH2, APH3, APH4, and APH5 were only able to chelate iron and copper ions among all metals studied and that APH3, APH4, and APH5 were also able to chelate mercury ion. However, none of them was able to chelate zinc, cadmium, and aluminum, thus exhibiting selective chelating activity that

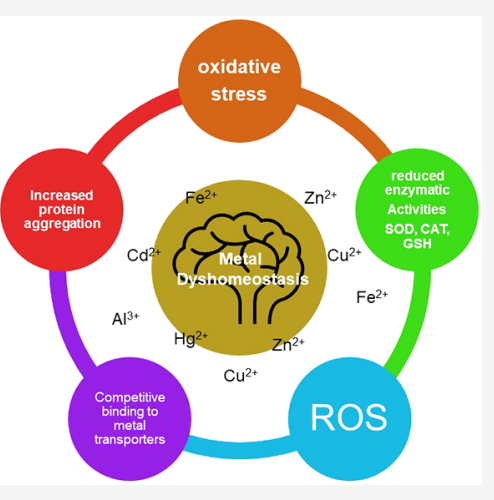
can be partly responsible for their neuroprotective action. Otherwise, our results indicate that their antioxidant effect is mediated through induction of the Nrf2 pathway that leads to overexpression of antioxidant enzymes. Finally, these compounds exhibited neuroprotective effects, reversing partially or completely the cytotoxic effects induced by the metals studied depending on the compound used. APH4 was the most effective and safe compound.

KEYWORDS: Metal cytotoxicity, neuroprotection, chelating activity, antioxidants, phenanthridones

\section{INTRODUCTION}

Several neurodegenerative disorders including Alzheimer's disease $(\mathrm{AD})$, Parkinson's disease (PD), Huntington's disease (HD), and amyotrophic lateral sclerosis (ALS), among others, are undergoing a worrying increase in incidence worldwide. Although the ultimate causes of these diseases remain unknown, the possible involvement of environmental factors in their development has been suggested. ${ }^{1-3}$ The rise in human industrial activity has exponentially increased the population's exposure to heavy metals and their body accumulation, leading to toxic effects. ${ }^{1-4}$ Brain accumulation of heavy metals, such as aluminum $(\mathrm{Al})$, cadmium $(\mathrm{Cd})$, and mercury $(\mathrm{Hg})$ due to overexposure, or essential metals, including iron (Fe), copper $(\mathrm{Cu})$ and zinc $(\mathrm{Zn})$ due to pathological circumstances, has been correlated with the development of neurodegenerative diseases. $^{1-8}$ Accumulation of metals in the brain was related with the induction of oxidative stress generation. ${ }^{1,2}$ Oxidative stress, which results from the mismatch between reactive oxygen species (ROS), reactive nitrogen species (RNS), and antioxidant defense can cause oxidative damage to cell structures and cell death. ${ }^{1,2}$ The central nervous system
(CNS) is the most metabolically active organ, resulting in a high production of superoxide radical anion $\left(\mathrm{O}_{2}^{-}\right)$, hydroxyl radical $(\mathrm{OH} \bullet)$, and hydrogen peroxide $\left(\mathrm{H}_{2} \mathrm{O}_{2}\right)$, thus being particularly susceptible to oxidative stress and ROS damage. ${ }^{1,2}$ Furthermore, ROS generation was reported to mediate the brain accumulation of oxidized, misfolded, and aggregated proteins such as tau-phosphorylated (p-tau), $\alpha$-synuclein $(\alpha$ syn), and $\mathrm{A} \beta$ peptides. After their accumulation, they induce neurofibrillary tangles, amyloid plaques, and Lewy bodies, the main hallmarks of $\mathrm{AD}$ and $\mathrm{PD}$, neuroinflammation, mitochondrial dysfunction, and finally neuronal cell death. ${ }^{1,2}$

Calcium and zinc regulate the activity of matrix metalloproteinases (MMPs), which control a variety of physiological processes. Under pathological conditions, MMPs overexpres-

Received: May 21, 2021

Accepted: August 19, 2021

Published: August 30, 2021 
Scheme 1. Synthesis of the Target Compounds APH $^{a}$

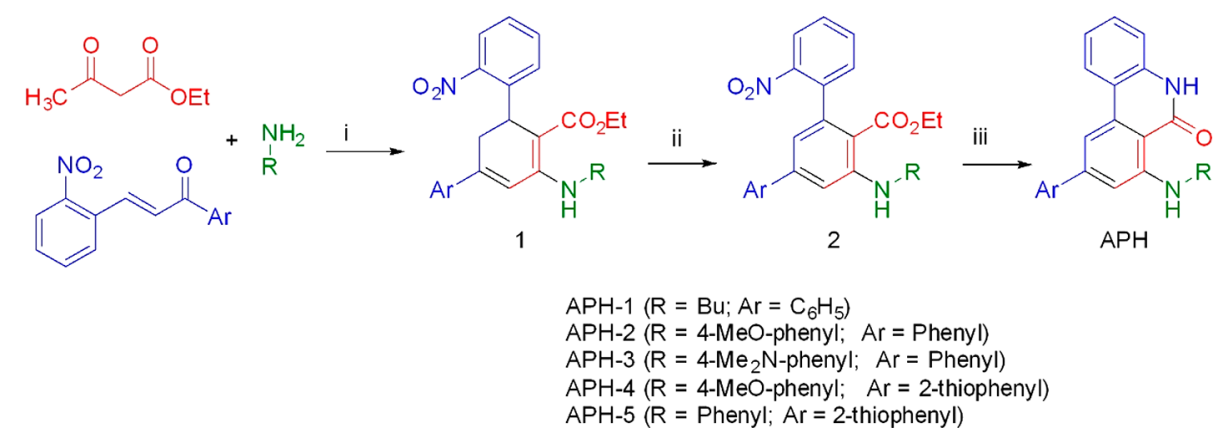

${ }^{a}$ Reagents and conditions: (i) EtOH, CAN (5\%) reflux, 16 h; (ii) DDQ (1.5 equiv), toluene, $2 \mathrm{~h}$ at room temperature; (iii) EtOH, $\mathrm{Pd} / \mathrm{C}$ (10\%), $\mathrm{H}_{2} 1 \mathrm{~atm}, 2 \mathrm{~h}$ at room temperature.

sion or abnormal expression has been related with the induction of brain damage and with neurodegenerative disease, including $\mathrm{AD}, \mathrm{PD}, \mathrm{HD}$, and $\mathrm{ALS}{ }^{9}$ Otherwise, heavy metals were also related to the induction of MMPs, which could lead to cytotoxicity. ${ }^{10}$ The main MMPs present in the brain are MMP-2/3/9/14, which play a key role in the neuroinflammatory processes and brain damage. ${ }^{11,12}$ Besides, MMPs dysfunction was related with the production of $\mathrm{A} \beta$, ptau, $\alpha$-synuclein, and other abnormal proteins related with neurodegenerative diseases, especially MMP-9.,13-15 Therefore, MMP inhibitors were tested to improve symptoms of different neurodegenerative diseases and to reduce the toxicity associated with metals. ${ }^{16}$

In this context, the control of metal accumulation in the CNS and its pathological effects is an important target in the development of new therapeutic agents against neurodegeneration and neurodegenerative disorders. In this sense, we have previously reported the discovery of new multitarget phenanthridin-6(5H)-one derivatives $(\mathrm{APH})$ that are able to inhibit MMP enzymes, reduce oxidative stress, and protect against ROS. ${ }^{17}$ Although these compounds were designed to present chelating activity, computational studies indicated binding to a distal region at the $S 1^{\prime}$ site, with no involvement of the catalytic zinc ion. ${ }^{16}$ Thus, it is necessary to confirm experimentally the role of the $\mathrm{Zn}^{2+}$ ion in MMPs inhibition by these compounds.

Furthermore, the neuroprotective effects shown for these compounds against oxidative stress and cell death induced by metals could be mediated through a direct ROS scavenger activity. The induction of cellular antioxidant enzymes, which reduce ROS, may also be involved, since they show neuroprotective and antioxidant action against hydrogen peroxide in SN56 cells. ${ }^{17}$ Nuclear factor erythroid 2-related factor $2(\mathrm{Nrf} 2)$ is a key factor in the transcription regulation of antioxidant cytoprotective enzymes such as superoxide dismutase 1 , catalase, glutathione peroxidase, $\mathrm{NAD}(\mathrm{P}) \mathrm{H}$ quinone oxidoreductase 1 , and heme oxygenase-1, among others. $^{18-20}$ Dysfunction of the Nrf2 pathway has been identified, in different neurodegenerative diseases, as a factor of oxidative stress generation. ${ }^{21-23}$ Besides, many metals were reported to alter the regulation of the $\mathrm{Nrf} 2$ pathway, leading to oxidative stress and cell death induction. ${ }^{24-27} \mathrm{Nrf2}$ levels are regulated by kelch-like ECH-associated protein 1 (Keap1), which under normal conditions binds to Nrf2 in the cytoplasm, promoting its degradation. However, under oxidative stress, Keap 1 is inactivated and releases $\mathrm{Nrf2}$, which is transported to the nucleus, inducing the expression of downstream pathway antioxidant enzymes. ${ }^{19,20}$ Another mechanism to avoid the oxidative stress, and other harmful actions of metals, is to sequester them with chelator compounds. Thus, as these compounds were designed to present chelating activity, they could also protect against metals toxicity through this mechanism.

In the context of the treatment of neurodegenerative diseases, it is crucial to find new multitarget drugs that reduce the neurotoxic effects of metals that may avoid the onset and progression of these diseases. In this sense, the use of molecules designed to possess antioxidant action and as metal ionophores to sequester, redistribute, and remove metals in the CNS is an attractive therapy to reduce the neurotoxic effect of metals in the brain. To reach this aim, we studied the chelating activity, the action on Nrf2 pathway, and the neuroprotective action against heavy and essential metals of a small library of 7-amino-phenanthridin-6-one derivatives that had been previously characterized as MMP inhibitors and found to exert the most neuroprotection against oxidative stress.

\section{RESULTS AND DISCUSSION}

Chemistry. The target compounds APH1-APH5 were synthesized as shown in Scheme 1 by our previously reported method. ${ }^{17}$ Thus, 4,6-diaryl-5,6-dihydroanthranylate derivatives 1 were obtained by a CAN-catalyzed multicomponent reaction between ortho-nitrochalcone, ethyl acetoacetate, and the suitable primary amines. This was followed by oxidative dehydrogenation of the central ring in the presence of 2,3dichloro-5,6-dicyano-1,4-benzoquinone (DDQ) and reductive cyclization to give the target compounds APH1-APH5 in good overall yield.

Metal-Chelating Properties of Compounds APH1APH5. $\mathrm{N}$ and $\mathrm{O}$ electron-donor atoms and carbonyl group assembled to a cyclic system are considered suitable for efficient interactions with metal cations. These binding moieties are present in some biological relevant compounds such as the tetracycline, ${ }^{28}$ 3-hydroxy flavonoids, ${ }^{29}$ and anthranilic acid, ${ }^{30}$ all of which have chelating properties. Thus, we designed the APH compounds as bidentate ligands to interact with the metal anions guest via a potential metalbinding site formed by the lactam group and the exocyclic nitrogen atom, hypothesizing that the substituents $\mathrm{R}$ on the nitrogen atom at C-7 position could modulate the affinity of the nitrogen atom for metals (Figure 1). For the current study, we selected compounds APH1-APH5 from our library, due to their higher activity on the selected targets (i.e., MMPs 
<smiles>CN(C)[C@H]1C(O)=C(C(N)=O)C(=O)[C@@]2(O)C(O)=C3C(=O)c4c(O)cccc4[C@@](C)(O)[C@H]3C[C@H]12</smiles><smiles>Nc1ccccc1C(=O)O</smiles>

Tetracycline<smiles>[R]c1cc(=O)c2c(O)cccc2o1</smiles>

5-hydroxi flavonoids
Antranilic acid<smiles>[Y10]Nc1cc([Al])cc2c1c(=O)[nH]c1ccccc12</smiles>

Figure 1. Hypothesized APH-metal interaction and some therapeutically useful chelating biomolecules.

inhibition and antioxidant activity), according to our previous studies. $^{17}$

The ability of the APH1-APH5 to bind $\mathrm{Fe}^{2+}, \mathrm{Cu}^{2+}, \mathrm{Zn}^{2+}$, $\mathrm{Hg}^{2+}, \mathrm{Cd}^{2+}$, and $\mathrm{Al}^{3+}$ was studied by ultraviolet-visible (UVvis) spectroscopy. This is one of the most widely used techniques to study chelation and to elucidate the stoichiometry of the formed metal complexes. ${ }^{31-34}$ To this end, the UV-vis spectra of the compounds alone and in the presence of one of the evaluated metals were compared. Blank solutions composed of dimethyl sulfoxide (DMSO) $100 \mathrm{mM}$ phosphate buffer at $\mathrm{pH} 7.30$ showed high absorption values between 190 and $240 \mathrm{~nm}$, and consequently only absorbances from 240 to $480 \mathrm{~nm}$ were considered.

When $\mathrm{FeCl}_{2}$ or $\mathrm{CuCl}_{2}$ were added to individual solutions containing APH1-APH5, and when $\mathrm{HgCl}_{2}$ was added to

solutions containing APH3, APH4, or APH5, new optical bands did not appear, and, therefore, the wavelengths corresponding to the maximum absorption bands of the $\mathrm{Fe}^{2+} /$ compound, $\mathrm{Cu}^{2+} /$ compound, or $\mathrm{Hg}^{2+} /$ compound solutions were similar to those of the compounds alone. By contrast, the analysis of solutions at different $\mathrm{Fe}^{2+} /$ compound, $\mathrm{Cu}^{2+}$ /compound, and $\mathrm{Hg}^{2+} /$ compound molar ratios evidenced important differences regarding the intensity of the absorption bands. The observed changes suggest an interaction between the tested compounds and $\mathrm{Fe}^{2+}, \mathrm{Cu}^{2+}$, and $\mathrm{Hg}^{2+}$ and, consequently, the formation of iron, copper, and mercury complexes, respectively. However, when the same experiments were performed with $\mathrm{ZnCl}_{2}, \mathrm{CdCl}_{2}$, or $\mathrm{AlCl}_{3}$ and solutions containing APH1-APH5, and when $\mathrm{HgCl}_{2}$ was added to solutions containing APH1 or APH2, no differences between spectra of the different $\mathrm{Zn}^{2+} /$ compound, $\mathrm{Cd}^{2+} /$ compound, $\mathrm{Al}^{3+} /$ compound, and $\mathrm{Hg}^{2+} /$ compound molar ratios and the compounds alone were observed. This absence of spectral changes suggests the lack of interaction between the tested compounds and $\mathrm{Zn}^{2+}, \mathrm{Cd}^{2+}, \mathrm{Al}^{3+}$, and $\mathrm{Hg}^{2+}$.

Due to the high spectral similarity between the compounds and their $\mathrm{Fe}^{2+}, \mathrm{Cu}^{2+}, \mathrm{Hg}^{2+}, \mathrm{Zn}^{2+}, \mathrm{Cd}^{2+}$, or $\mathrm{Al}^{3+}$ complexes, derivative spectroscopy was applied in order to enhance differences among spectra, to resolve overlapping bands, to reduce the effects of other absorbing compounds, and to eliminate the background. Once UV-vis spectra were registered, mathematical methods were used to generate the first-order derivative spectra. Our analysis shows excellent results in enhancing differences among spectra, increasing the resolution of the overlapped bands, reducing the effects of other absorbing compounds, and eliminating the background. In fact, as the first derivative spectrum passes through zero at

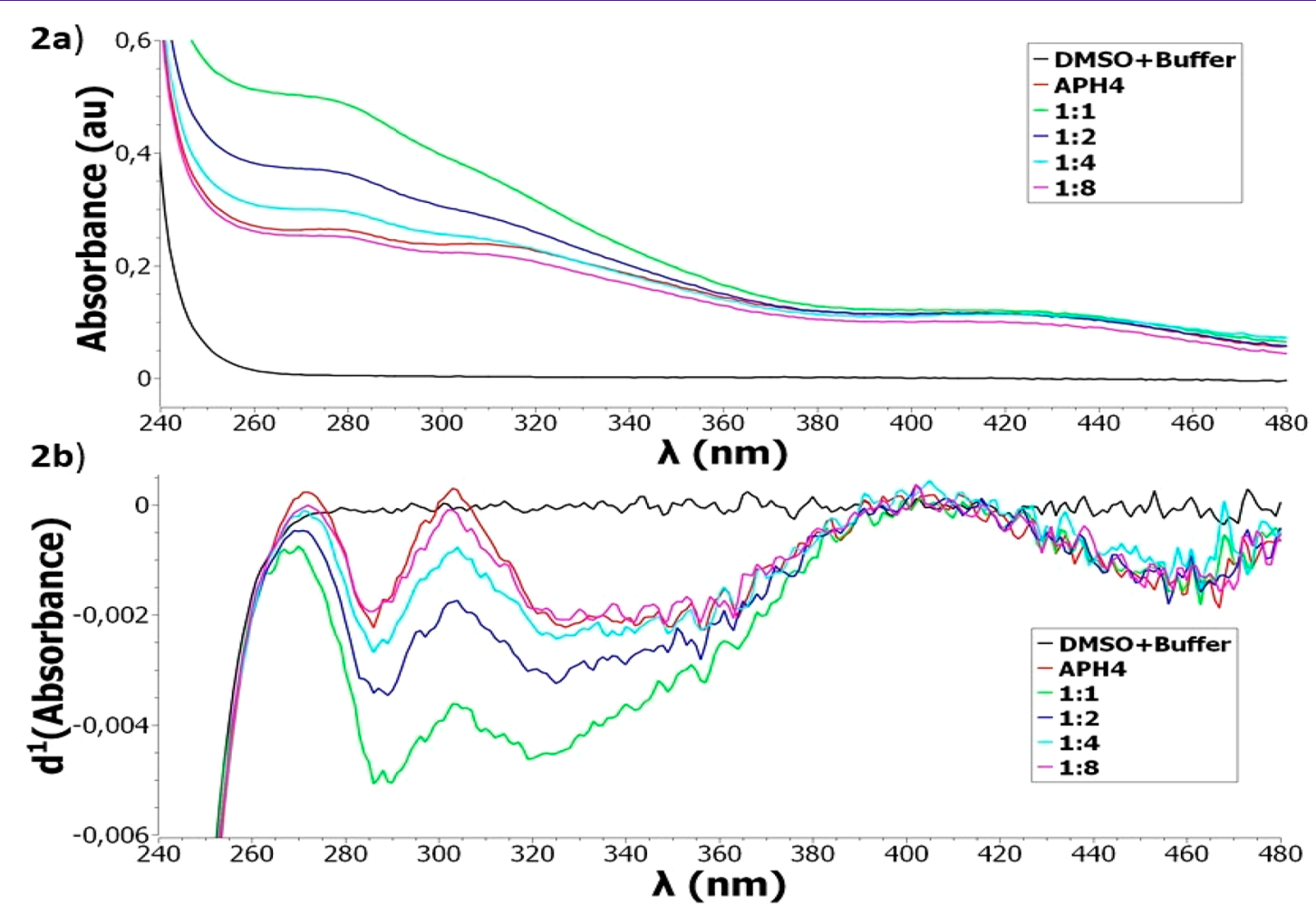

Figure 2. UV-vis spectra (a) and first-order derivative absorption spectra (b) of APH4 alone and in the presence of $\mathrm{FeCl}_{2}$ in buffer (100 $\mathrm{mM}$ phosphate, $\mathrm{pH}=7.30)$ at room temperature. $[\mathrm{APH} 4]=50 \mu \mathrm{M}$ and $\left[\mathrm{Fe}^{2+}\right]=50,25,12.5$, and $6.25 \mu \mathrm{M}$, corresponding to stoichiometries $1: 1,1: 2$, $1: 4$ and $1: 8$, respectively. 

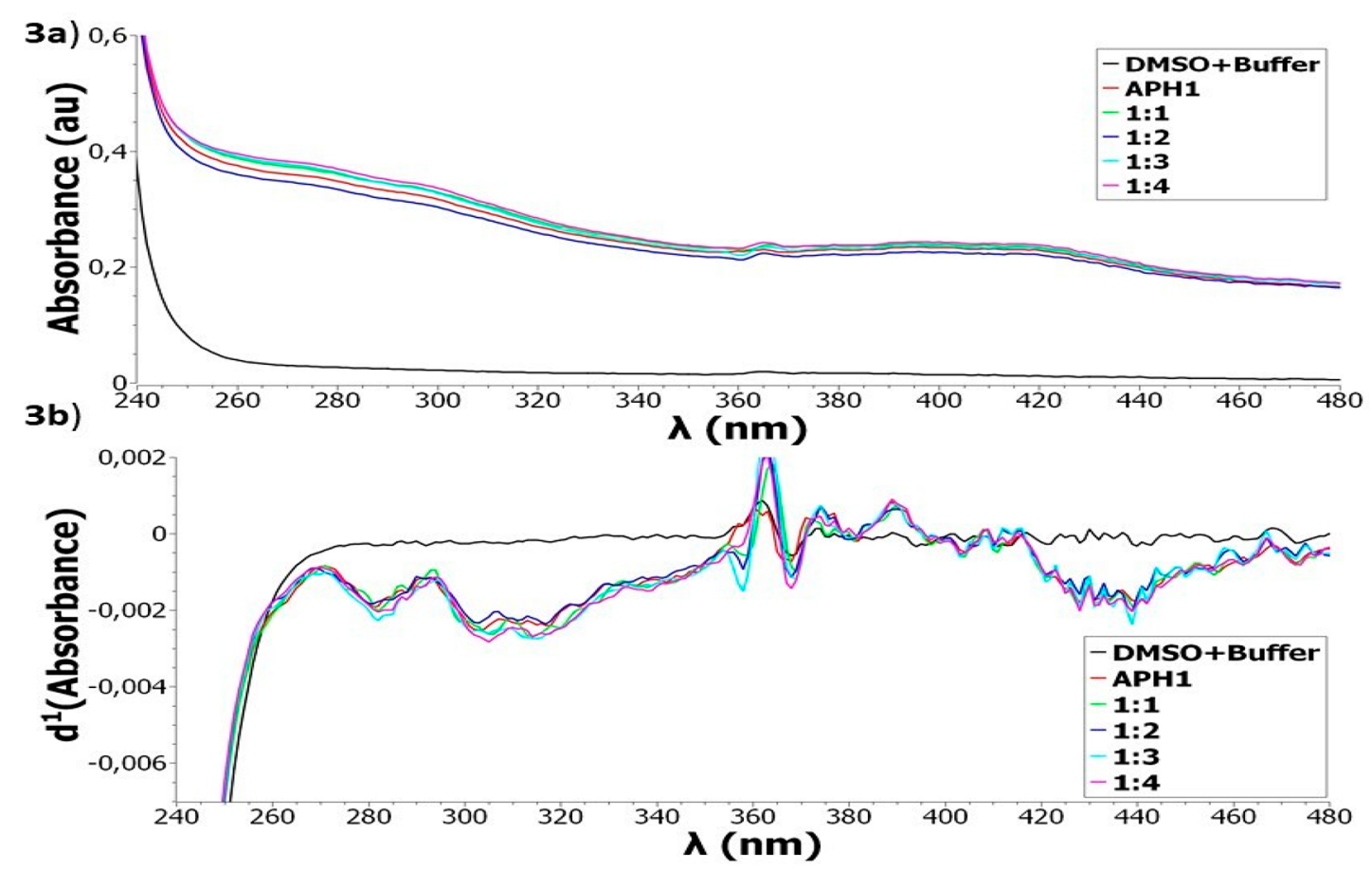

Figure 3. UV-vis spectra (a) and first-order derivative absorption spectra (b) of APH1 alone and in the presence of $\mathrm{CdCl}_{2}$ in buffer ( $100 \mathrm{mM}$ phosphate, $\mathrm{pH}=7.30)$ at room temperature. $[\mathrm{APH1}]=50 \mu \mathrm{M}$ and $\left[\mathrm{Cd}^{2+}\right]=50,25,16.7$, and $12.5 \mu \mathrm{M}$ corresponding to stoichiometries $1: 1,1: 2$, $1: 3$ and $1: 4$, respectively.

the same wavelength as $\lambda_{\max }$ of the absorbance band, the spectral differences are highlighted. Thus, the analysis of derivative spectra allowed to confirm, through a resolution enhancement effect, that APH1-APH5 were able to interact with $\mathrm{Fe}^{2+}$ and $\mathrm{Cu}^{2+}$. Moreover, it was verified that APH3, APH4, and APH5 were also able to interact with $\mathrm{Hg}^{2+}$ and, thus, to form iron, copper or mercury complexes. Otherwise, no changes were appreciated in $\mathrm{Hg}^{2+}$-APH1 and $\mathrm{Hg}^{2+}$-APH2 and neither in $\mathrm{Zn}^{2+}, \mathrm{Cd}^{2+}$, or $\mathrm{Al}^{3+}$ with APH1-APH5 from derivative spectra.

The stoichiometry of the chelated iron, copper, and mercury compounds were estimated by means of the derivative spectra collected under two different conditions: (i) maintaining constant the metal ion concentration $(50 \mu \mathrm{M})$ and varying the compound concentration and (ii) maintaining constant the compound concentration $(50 \mu \mathrm{M})$ and varying the metal concentration. The results showed that the five compounds evaluated presented a similar behavior regarding $\mathrm{Fe}^{2+}$ and $\mathrm{Cu}^{2+}$ chelation. Figure $2 \mathrm{a}, \mathrm{b}$ shows the UV-vis spectra registered for $\mathrm{Fe}^{2+}$-APH4, as an example of metal-compound interaction. Figure 2a evidenced differences between absorbance spectra of the compound alone and in the presence of $\mathrm{FeCl}_{2}$. Nevertheless, differences among the spectra corresponding to different stoichiometries are not properly appreciated. However, as depicted in Figure $2 b$, first-order derivative absorption spectra revealed some differences depending on the evaluated stoichiometry. The maximum absorption band at $280 \mathrm{~nm}$ (Figure 2a) appeared in all stoichiometries, being associated with the negative band at $290 \mathrm{~nm}$ as reflected in the derivative spectra (Figure $2 \mathrm{~b}$ ). This band may correspond to the absorption of the iron complex as it increases, as metal concentration reaches its maximum in Figure 2a. Otherwise, a ligand absorption band was observed at $300 \mathrm{~nm}$, which overlaps with the optical band of the $\mathrm{Fe}^{2+}$ complex. This effect is shown in Figure $2 b$, where the derivative spectra of the compound alone passed through 0 at $300 \mathrm{~nm}$ wavelength, in contrast with the different stoichiometries. By analysis of the first-order derivative spectra (Figure 2b), the stoichiometry of the $\mathrm{Fe}^{2+}$-APH4 complex is consistent with a $1: 1 \mathrm{Fe}^{2+} /$ compound molar ratio. However, complexes of different stoichiometry could be simultaneously formed.

Similar observations were made for $\mathrm{Fe}^{2+}$ and $\mathrm{Cu}^{2+}$ with APH1-APH5 and for $\mathrm{Hg}^{2+}$ with APH4 and APH5. The spectra revealed bands that could be associated with the iron complexes at wavelengths of $280 \mathrm{~nm}\left(\mathrm{Fe}^{2+}-\mathrm{APH1}\right), 270$ and $305 \mathrm{~nm}\left(\mathrm{Fe}^{2+}\right.$-APH2), $280 \mathrm{~nm}\left(\mathrm{Fe}^{2+}\right.$-APH3), and $270 \mathrm{~nm}$ (Fe ${ }^{2+}$-APH5), while the copper complexes showed bands at 275 and $300 \mathrm{~nm}\left(\mathrm{Cu}^{2+}\right.$-APH1), $265 \mathrm{~nm}\left(\mathrm{Cu}^{2+}\right.$-APH2), 260 $\mathrm{nm}\left(\mathrm{Cu}^{2+}\right.$-APH3 $), 265 \mathrm{~nm}\left(\mathrm{Cu}^{2+}\right.$-APH4), and $270 \mathrm{~nm}\left(\mathrm{Cu}^{2+}\right.$ APH5). Moreover, with the mercury complexes bands appeared at 295 and $300 \mathrm{~nm}\left(\mathrm{Hg}^{2+}\right.$-APH4) and 300 and $305 \mathrm{~nm}\left(\mathrm{Hg}^{2+}\right.$-APH5 $)$. Once again the $1: 1 \mathrm{metal} / \mathrm{compound}$ molar ratio seems to be the main common stoichiometry for the formed complexes. However, for $\mathrm{Hg}^{2+}$-APH3, showing an absorption band at $305 \mathrm{~nm}$, the stoichiometry remains unclear.

Figure 3a,b shows the $\mathrm{Cd}^{2+}$-APH1 spectra, as an example of an noninteracting metal-compound. There were no differences between compound bands (APH1) and metal-compound bands at different molar ratios $(1: 1-1: 4)$ in the UV-vis spectra (Figure 3a). These differences were not appreciated in the first derivative spectra (Figure $3 \mathrm{~b}$ ). Similar observations were deduced for $\mathrm{Zn}^{2+}, \mathrm{Cd}^{2+}$ and $\mathrm{Al}^{3+}$ with APH1-APH5 and for $\mathrm{Hg}^{2+}$ with APH1 and APH2. The rest of UV-vis and firstorder derivative absorption spectra data for APH compounds and the metals studies are shown in Figures S3-S7 in the Supporting Information.

In our previous work, we showed that APHs are able to inhibit MMP enzymes and computational studies suggested that this inhibitory activity is not mediated by the chelation of $\mathrm{Zn}^{2+}$ ion at the catalytic site, as is the case for many other 

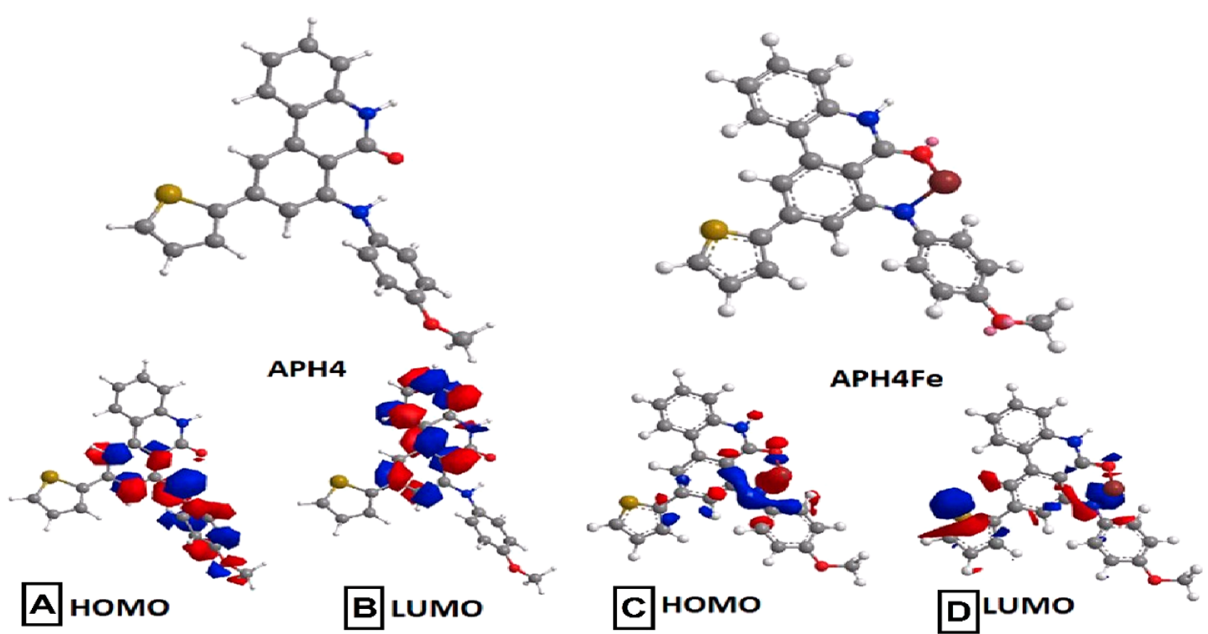

Figure 4. Optimized molecular structure of the APH4 and APH4-Fe complex (upper) and their corresponding HOMOs (A and C) and LUMOs (B and D). Color scheme: Carbon is gray, hydrogen is white, nitrogen is blue, oxygen is red, and iron is brown. HOMOs and LUMOs are shown in red and blue.

Table 1. Predicted Physicochemical Properties of APH Compounds

\begin{tabular}{|c|c|c|c|c|c|c|}
\hline property & APH1 & APH2 & APH3 & APH4 & APH5 & favorable value \\
\hline \multicolumn{7}{|c|}{ Drug-likeness } \\
\hline molecular weight $(\mathrm{g} / \mathrm{mol})$ & 342.44 & 392.46 & 405.50 & 398.49 & 368.46 & $\leq 500$ \\
\hline $\log P$ & $5.56^{a} ; 5.03^{b}$ & $6.10^{a} ; 5.16^{b}$ & $6.16^{a} ; 5.18^{b}$ & $6.19^{a} ; 5.21^{b}$ & $6.15^{a} ; 5.31^{b}$ & $\leq 5$ \\
\hline no. rotatable bonds & 5 & 4 & 4 & 4 & 3 & $\leq 7$ \\
\hline no. H-bond acceptors & 2 & 3 & 3 & 2 & 3 & $\leq 10$ \\
\hline no. H-bond donors & 2 & 2 & 2 & 2 & 2 & $\leq 5$ \\
\hline
\end{tabular}

${ }^{a}$ Prediction with ADMETsar version 2. ${ }^{b}$ Prediction with Swiss ADME.

MMP inhibitors. ${ }^{17}$ Our present results show that APH compounds tested were not able to chelate $\mathrm{Zn}^{2+}$ ion, confirming the computational results. Further analysis should be performed to determine the mode of action behind MMPs inhibition by APHs.

Highest Occupied Molecular Orbital and Lowest Unoccupied Molecular Orbital analysis. The obtained results also show that all five APH compounds are able to bind to $\mathrm{Fe}^{2+}$ and $\mathrm{Cu}^{2+}$, while they are unable to bind to bigger cations such as $\mathrm{Cd}^{2+}, \mathrm{Al}^{3+}$, and $\mathrm{Hg}^{2+}$. The $\mathrm{Hg}^{2+}$ binding capacity of APH3-APH5 is probably due to coordination with the nitrogen atom of dimethylamino group for APH3 and with the thiophen sulfur of APH4 and APH5. Furthermore, $\mathrm{Zn}^{2+}$ and $\mathrm{Cd}^{2+}$ ions usually form five-membered complexes with bidentate species, while $\mathrm{Fe}^{2+}$ and $\mathrm{Cu}^{2+}$ preferentially lead to the formation of six-membered metallocycles, consistent with the observed results.

To corroborate our experimental results of the chelating capacity of APH compounds and to relate these results with the compound structures, we studied highest occupied molecular orbital (HOMO) and lowest unoccupied molecular orbital (LUMO) orbital energies and energy gaps for the APH compounds and for the corresponding APH-Fe complexes (Table S1). Iron was chosen since, together with copper, it was chelated by all APH compounds. Our results for compounds APH1-APH5 show that the proposed metal binding site was accessible (without impediment from the substituent of the exocyclic nitrogen in the most stable conformation calculated) for the five compounds (Figure S1). It was also observed that the HOMO orbital is mainly extended on the alkyl or the $\pi$ system at the C-7 position. Particularly, for APH3, the charge density is concentrated on the dimethylamino group. Finally, the HOMO-LUMO energy gap (7.049, 7.799, 4.494, 5.982, and $6.643 \mathrm{eV}$ for APH1-APH5, respectively), calculated at Merck molecular force field 94 (MMFF94) level, is compatible with complex formation.

The HOMO and LUMO levels for the APH compounds complexed with iron showed a reduction of gap energy of 0.917, 0.712, 3.922, 0.145, $0.299 \mathrm{eV}$ for APH1-Fe to APH5-Fe complexes, respectively (Table S1), indicating a high stability for the complexes. The highest reduction of gap energy was observed in AHP4-Fe, showing that this compound is the most stable (Table S1) and therefore that AHP4 has the highest chelating activity, a prediction that correlates well with the fact that this compound presented the best neuroprotective activity as shown below. Taking APH4 as an example, it is apparent that the exocyclic nitrogen gives a higher contribution to the HOMO levels of APH4 than to the HOMO levels of the APH4-Fe complex (Figure 4a,c), which indicates that the nitrogen atom depletes charge from the $\mathrm{Fe}^{2+}$ ions. Additionally, the presence of an aromatic amine at C-7 seems to stabilize the iron complex in comparison to the alkyl amine (see APH1-Fe and APH2-Fe in Table S1), and the amine group on the aromatic ring seems to destabilize the complex compared to the methoxy group (see APH3-Fe in Table S1). Finally, the presence of a thiophene at the C-9 position appears to lead to a smaller gap than the presence of a benzene ring (compare APH4-Fe and APH2-Fe in Table S1).

Therefore, although the number of compounds studied is somewhat limited to conclude a structure-complex formation ability relationship, it could be confirmed that their ability to interact with $\mathrm{Fe}^{2+}$ and $\mathrm{Cu}^{2+}$ does not depend on the 

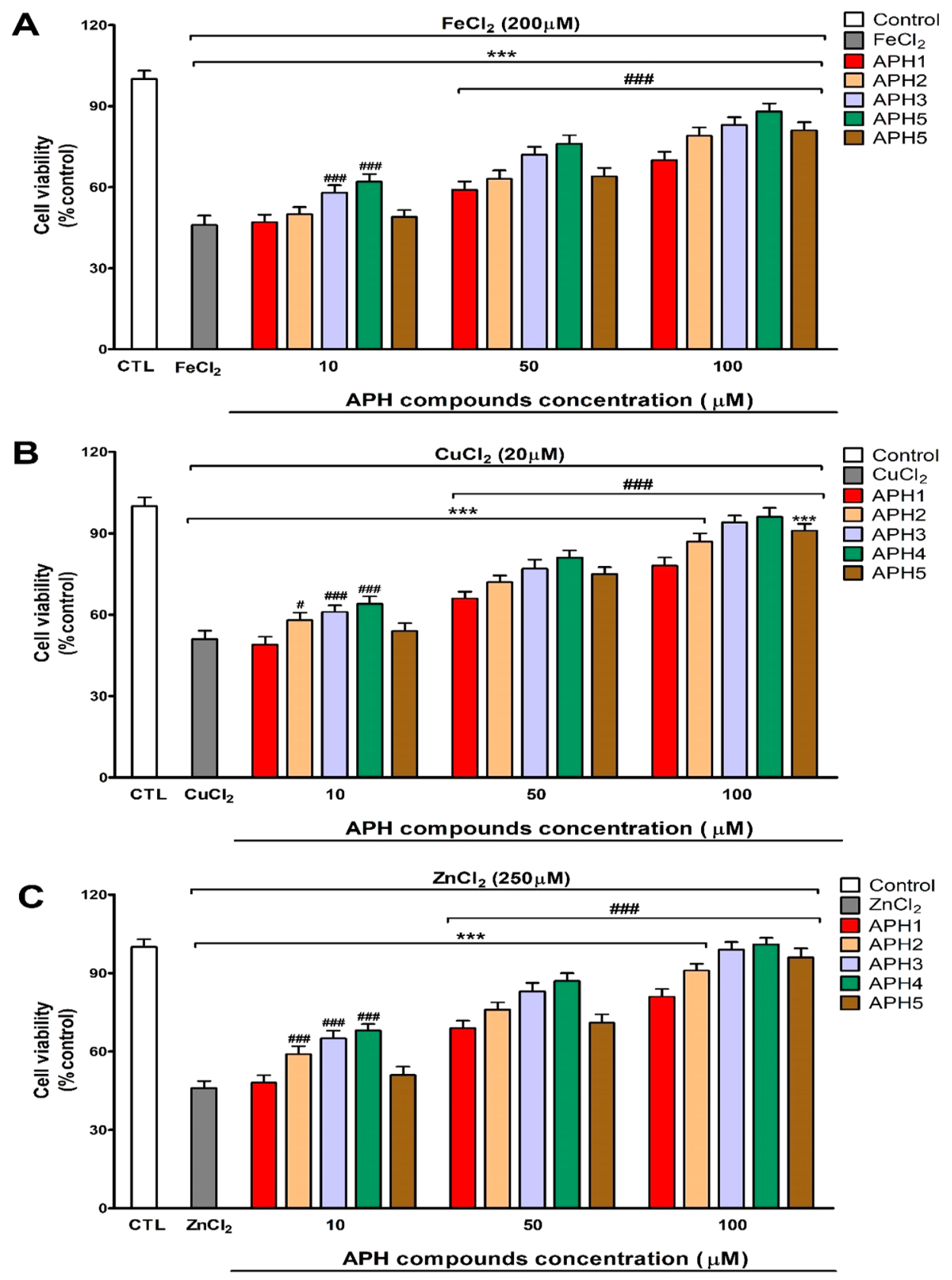

Figure 5. Cell viability effects after $\mathrm{FeCl}_{2}$ (A) for $\mathrm{CuCl}_{2}$ (B) and $\mathrm{ZnCl}_{2}$ (C) treatment with or without selected APH compounds (10-100 $\mu \mathrm{M}$ ) pretreatment. Data represent the mean \pm SEM of three independent experiments in triplicate. $* * * p \leq 0.001$ compared to control; ${ }^{\#} p \leq 0.05$ and \#\#\# 0.001 compared to metal treatment.

substituent of 7-amino phenanthridi-6-one skeleton. The computational analysis also revealed that phenyl moieties on the exocyclic nitrogen by the iron complex stabilizes the HOMO charge. Thus, the chelating cavity is suitable for small metal cations.

Computational Prediction of Physicochemical and Absorption, Distribution, Metabolism, Excretion, and Toxicological Properties of APH Compounds. According to the ADMETsar version 2.0 and swissADME software analysis, as shown in Table 1, the APH compounds satisfied all the values required except for the lipophilicity values, ${ }^{35}$ which are slightly above the Lipinski limit.

Based on the results shown in Table S2, it can be assumed that APH compounds have favorable intestinal absorption and Caco2 cell permeability. The CNS distribution properties of our molecules was estimated through the calculation of the brain distribution parameter, which can evaluate the ability of small molecules to cross the blood-brain barrier (BBB) and be distributed into the brain. The predictions of the two methods used were fully consistent for APH1, where both predicted a good BBB penetration ability. For APH2, APH3, APH4 and APH5, ADMETsar version 2.0 showed good BBB penetration data, but swissADME gave borderline negative results. The metabolic properties of these compounds were estimated according to the predicted inhibitory capacity of cytochrome P450 isoforms Cyp1a2, Сyp2c19, Сyp2c9, and Cyp2d6. As an additional piece of information connected to the prediction of pharmacokinetic properties, glycoprotein substrate capacity was assessed, but again the results from the two softwares were not homogeneous. To summarize, it was found that, although 


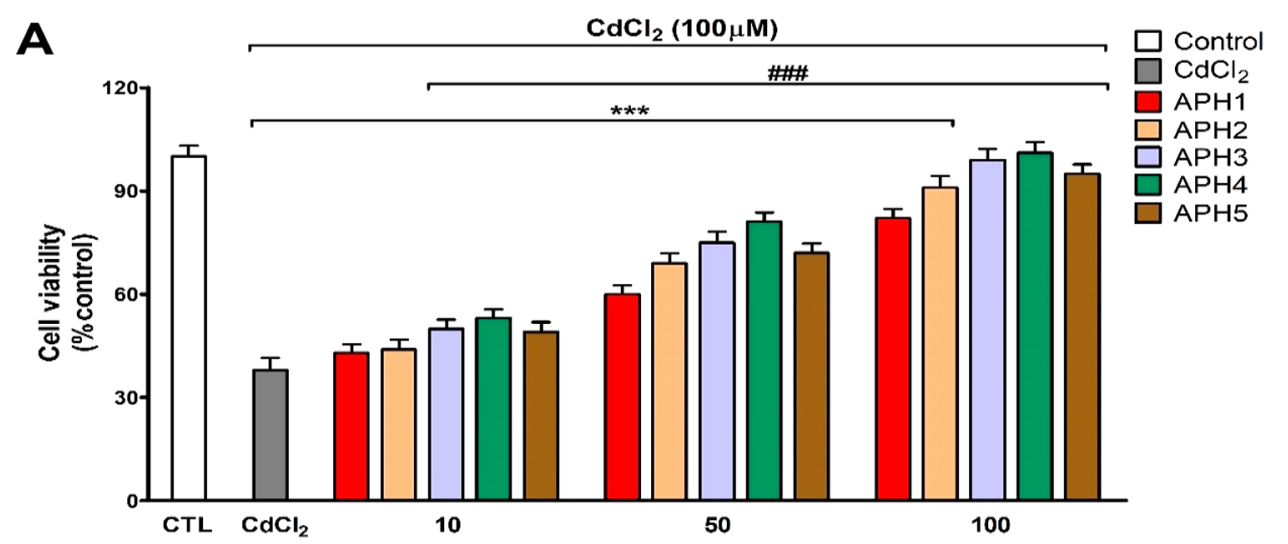

APH compounds concentration $(\mu \mathrm{M})$
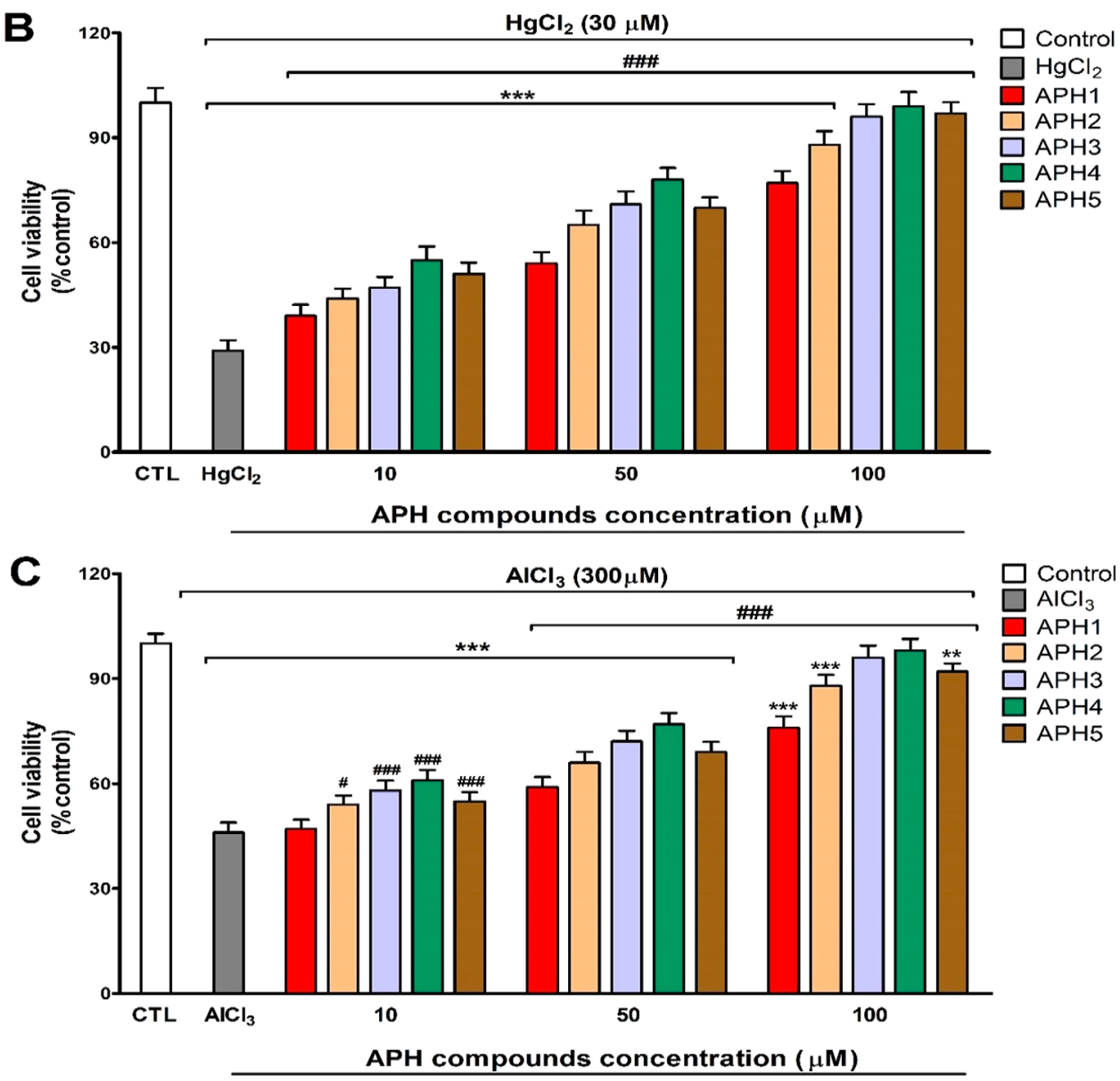

Figure 6. Cell viability effects after $\mathrm{CdCl}_{2}$ (A) for $\mathrm{HgCl}_{2}$ (B) and $\mathrm{AlCl}_{3}$ (C) treatment with or without selected APH compounds (10-100 $\mu \mathrm{M}$ ) pretreatment. Data represent the mean \pm SEM of three independent experiments in triplicate. $* * p \leq 0.01$ and $* * * p \leq 0.001$ compared to control; $p \leq 0.05$ and ${ }^{\# \# \#} p \leq 0.001$ compared to metal treatment.

the lipophilicity scores may need to be further optimized, the predicted absorption, distribution, metabolism, excretion, and toxicological (ADMET) properties of the APH compounds characterize them as a suitable starting point to develop a leader compound. All the predicted characteristics of APHs in passing the $\mathrm{BBB}$, permeability to Caco- 2 cells, interaction of the compound with the cytochrome P450 isoenzymes and Pglycoproteins are shown in Table S2.

Neuroprotective Activity of Compounds APH1APH5 against Metal-Induced Cell Viability Reduction. APH1-APH5 were selected because they were, out of all the
APH compounds tested, the ones with less cytotoxic effects, also presenting the most potent antioxidant and neuroprotective effect against ROS isults. ${ }^{17}$ Thus, the treatment of SN56 cells with APH1-APH5 at different concentrations (1, $10,50,100,150$, and $200 \mu \mathrm{M})$ only started to reduce cell viability at $200 \mu \mathrm{M}$ (Figure S2). Thus, the range of 10-100 $\mu \mathrm{M}$ concentrations was selected, as it has shown no cytotoxicity, to tests APHs neuroprotective effects.

Treatment of neurons with the heavy (cadmium, mercury, and aluminum) and essential (iron, copper, and zinc) metals' produced a reduction of cell viability. This effect was avoided 
A
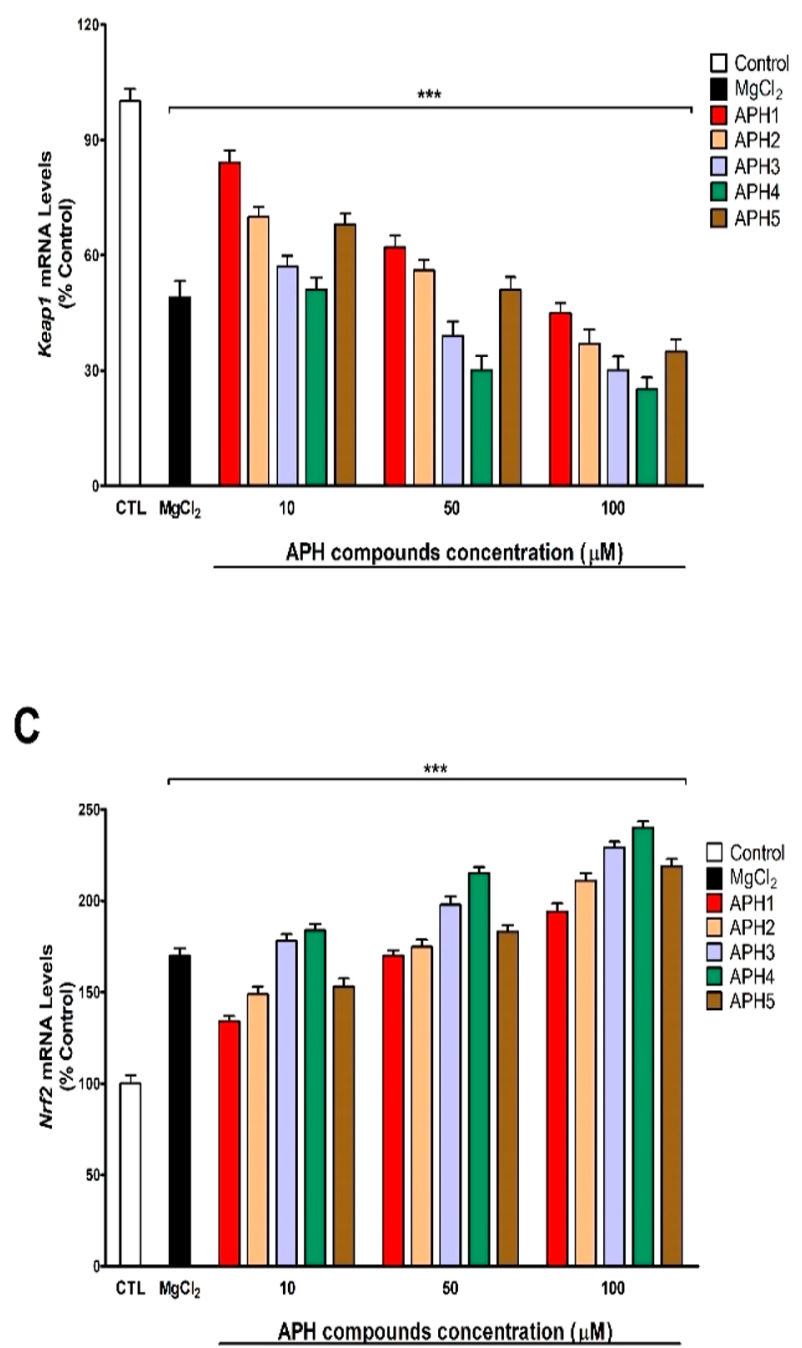

B
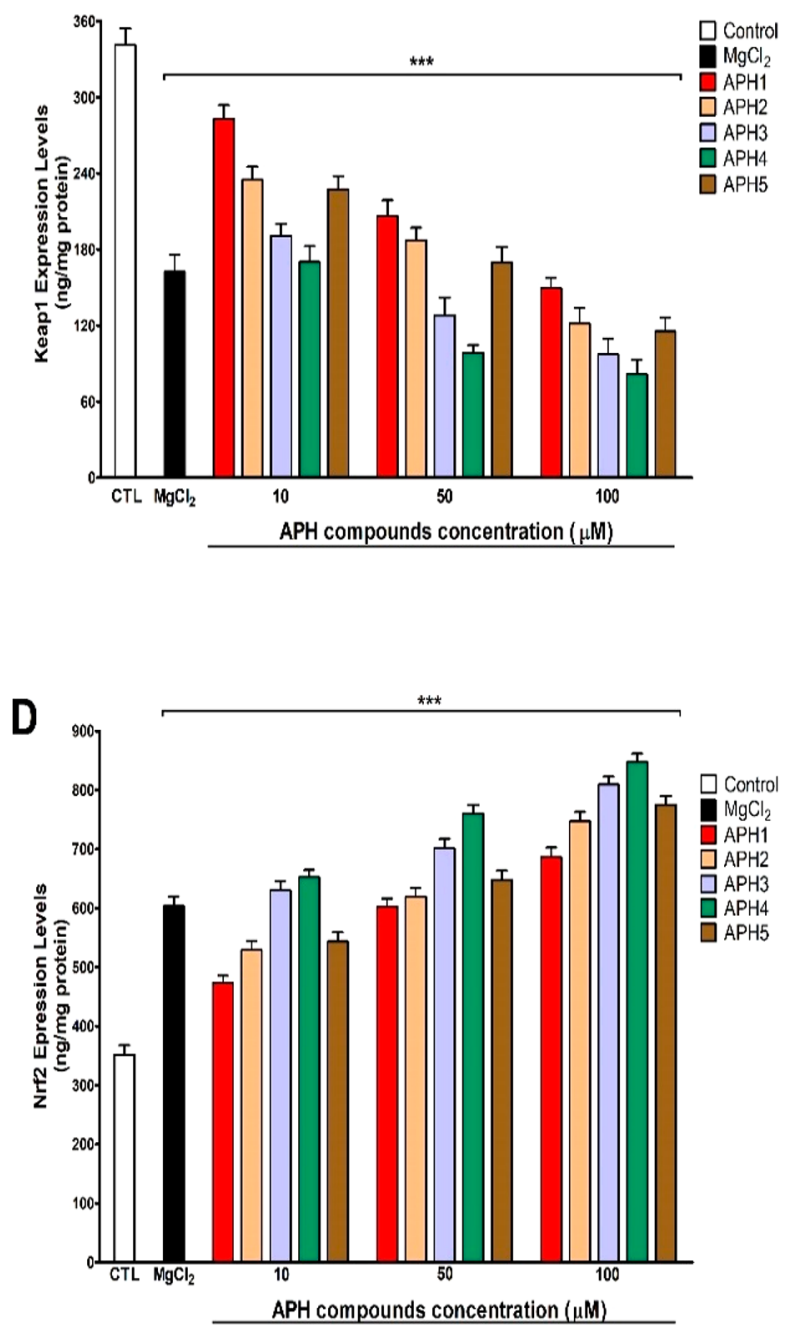

Figure 7. Obtained results from Keap1 (A) and Nrf2 (C) gene expression and Keap1 (C) and Nrf2 (D) protein expression after $24 \mathrm{~h}$ treatment. Keap 1 and $\mathrm{Nrf} 2$ gene and protein expressions are compared with controls [cells treated with vehicle were the negative control]. Each bar represents mean \pm SEM of three separate experiments from cells of different cultures, each one performed in triplicate and presented as percent untreated control for gene expression and in $\mathrm{ng} / \mathrm{mg}$ protein form protein expression. $* * * p<0.001$ significantly different from controls.

completely or partially when cells were pretreated with APH1-APH5 in a concentration-dependent way (Figures 3 and 4). The heavy and essential metals studied were reported to induce neuronal cell death, ${ }^{1-8}$ supporting our results.

The protection against essential metals started from $10 \mu \mathrm{M}$ after pretreatment with AHP2, APH3, or APH4. For $\mathrm{FeCl}_{2}$, pretreatment with APH2 started the protection from $50 \mu \mathrm{M}$ as well as after the pretreatment with APH1 or AHP2 in cells treated with essential metals (Figure $5 \mathrm{a}-\mathrm{c}$ ). Besides, in cells treated with heavy metals, the APH1-APH5 pretreatment started to protect, from $10 \mu \mathrm{M}$, against the cell viability reduction observed after heavy metals treatment alone. For $\mathrm{CdCl}_{2}$, pretreatment with $\mathrm{APH1}$ and $\mathrm{APH} 2$ and for $\mathrm{AlCl}_{3}$, pretreatment with APH1 started cell death reversion from 50 $\mu \mathrm{M}$ (Figure $5 \mathrm{a}-\mathrm{c}$ ). Pretreatment with compounds APH3 and APH4, at the concentration of $100 \mu \mathrm{M}$, protected completely against the cytotoxic effects induced by all metals studied except for $\mathrm{FeCl}_{2}$ (Figures 5 and 6). Besides, pretreatment with compound APH5, at the concentration of $100 \mu \mathrm{M}$, only protected completely against the cytotoxic effects induced by $\mathrm{ZnCl}_{2}, \mathrm{CdCl}_{2}$, and $\mathrm{HgCl}_{2}$ (Figures 5 and 6).
The differences observed in the concentrations from which these compounds start to show protection against the metalinduced cytotoxic effects can be ascribed to the different potency in their different protective mechanisms. These differences may also be produced because each APH compound may induce different mechanisms that mediate the neuroprotection observed. In this sense, our chelating studies suggest that $\mathrm{Zn}^{2+}, \mathrm{Cd}^{2+}$, and $\mathrm{Al}^{3+}$ ions are not chelated by any of the APH compounds studied and that $\mathrm{Hg}^{2+}$ is only chelated by APH3, APH4, and APH5 compounds. This fact indicates that the neuroprotection observed against zinc, cadmium, and aluminum by all these compounds or against mercury by compounds APH1 and APH2 is not mediated by their chelating activity and other mechanisms are involved. Besides, the protection observed against iron, and probably copper, at the lowest compound concentrations should be limited, especially for iron. The chelating activity at the higher concentrations used of these metals only blocked a very limited part of the metal pool, suggesting other mechanisms are involved. In this sense, we previously described that these compounds are MMP inhibitors and present antioxidant 
A

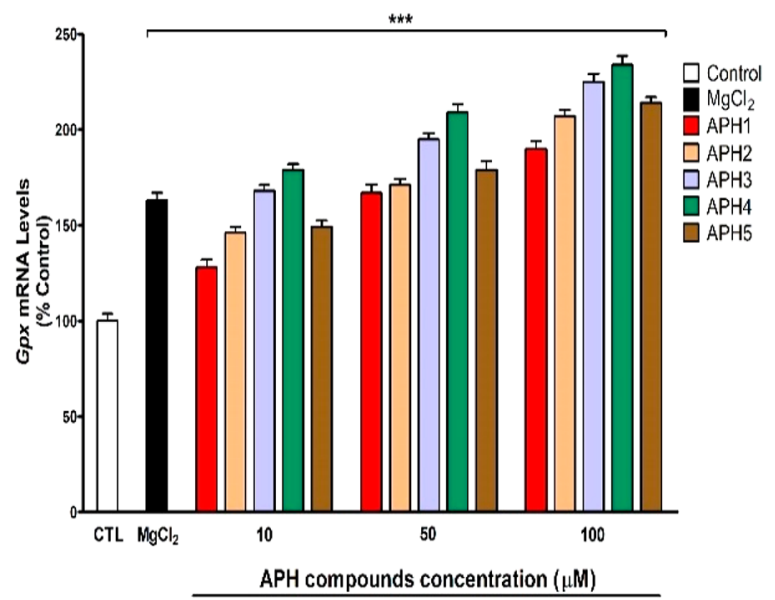

C

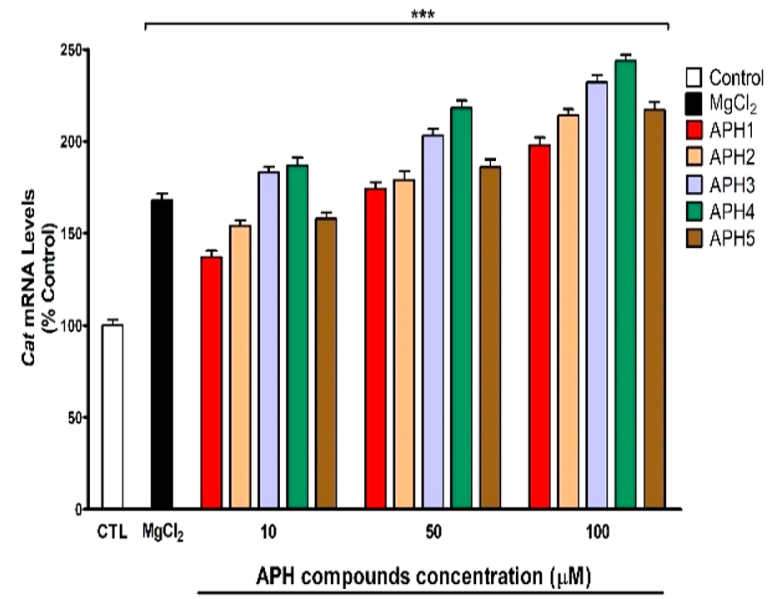

B

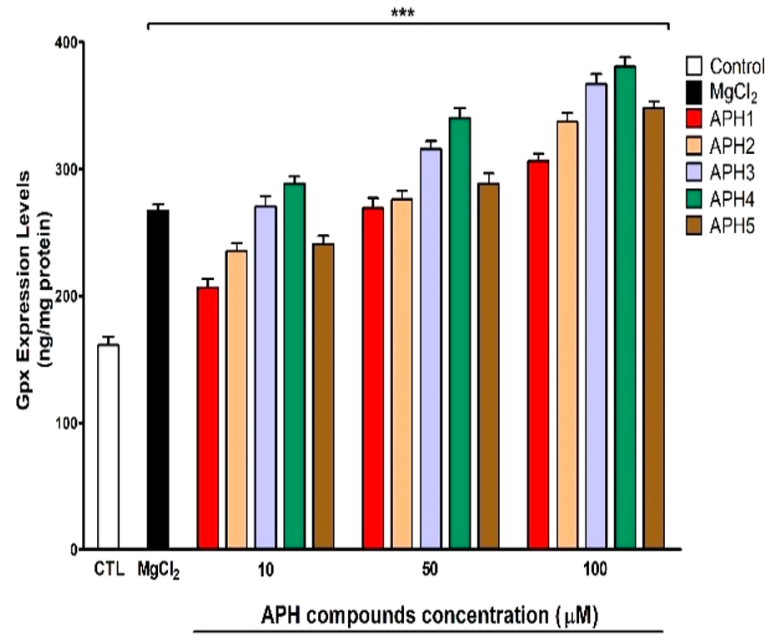

D

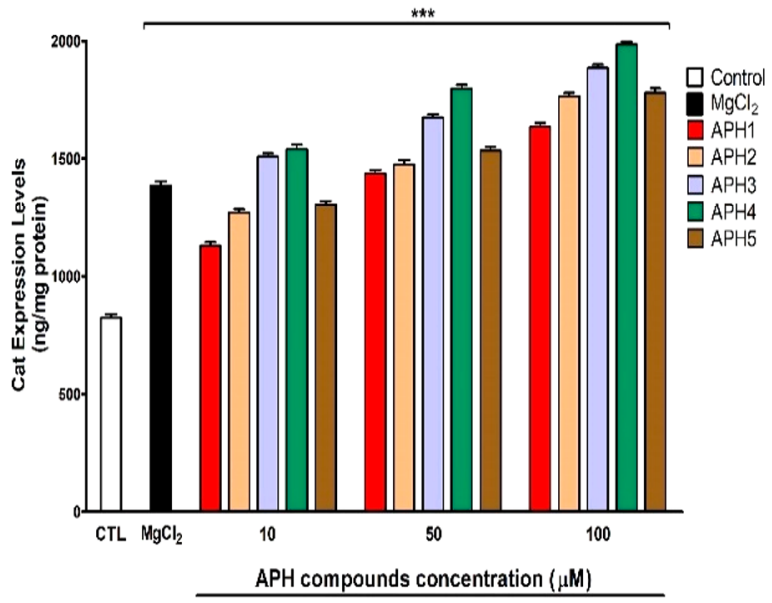

Figure 8. Obtained results from Gpx (A) and Cat (B) gene expression and Gpx (C) and Cat (D) protein expression after 24 h treatment. Gpx and Cat gene and protein expressions are compared with controls [cells treated with vehicle were the negative control]. Each bar represents mean \pm SEM of three separate experiments from cells of different cultures, each one performed in triplicate and presented as percent untreated control for gene expression and in $\mathrm{ng} / \mathrm{mg}$ protein for protein expression. $* * * p<0.001$ significantly different from controls.

activity, ${ }^{17}$ which could participate in these neuroprotective effects. The greater neuroprotective action observed after pretreatment with all metals studied was mediated by compound APH4. This effect is correlated with our previous results on MMPs inhibition and antioxidant effect ${ }^{17}$ that support that these mechanisms are probably involved in the neuroprotective effects of these compounds.

NRF2 Pathway Induction by Compounds APH1APH5. The treatment of SN56 cells with compounds APH1APH5 induced a concentration-dependent decrease in the gene and protein expression of Keapl (Figure 7a,b). A correlated concentration-dependent increase in the gene and proteins expression of $\mathrm{Nrf} 2$ factor (Figure $7 \mathrm{c}, \mathrm{d}$ ) was observed. Besides, the gene and protein expression of Gpx and Cat enzymes was increased, in a concentration-dependent way, after the treatment with compounds APH1-APH5 (Figures $8 \mathrm{a}-\mathrm{c})$. Thus, APH compounds induce Nrf2 pathway.

Keap1 protein regulate Nrf2 proteins levels, inducing its degradation under no stress situations, through proteasome degradation. However, after stress situations, like ROS generation, its affinity for Nrf2 protein is reduced, increasing Nrf2 levels. Nrf2 is then translocated to the nucleus where it acts as the master regulator of the expression of different antioxidant enzymes such as Gpx and Cat among others. ${ }^{18-20,36,37}$ Keap1 downregulation was reported to induce Nrf2 protein overexpression and the enzymes regulated by it. $^{38,39}$ Besides, Keap1 and Nrf2 gene expression was reported to be regulated by different factors like microRNAs (miRNAs) or different transcription factors. ${ }^{38,40} \mathrm{Nrf} 2$ protein levels were shown to be altered by mechanisms independent of Keap 1 protein action. ${ }^{36}$ In this sense, we showed that compounds APH1-APH5 induced the Nrf2 pathway by different mechanisms. On one hand, they induce the Nrf2 pathway by an independent mechanism of Keap1 regulation of $\mathrm{Nrf} 2$ proteins degradation, since these compounds act to upregulate the Nrf2 gene expression. On the other hand, compounds APH1-APH5 regulate the Nrf2 pathway by a mechanism dependent on keap1, since they downregulated Keap1 gene expression, contributing to the overexpression of $\mathrm{Nrf} 2$ protein and of the Gpx and Cat antioxidant enzymes regulated by it. 


\section{A}

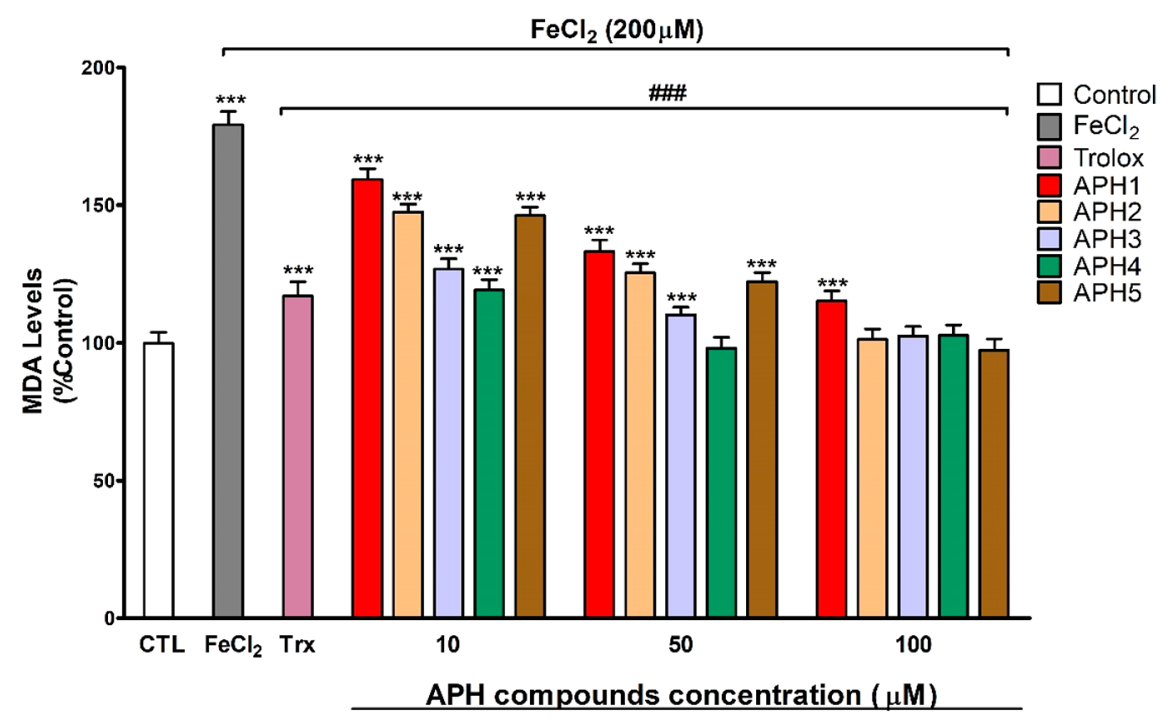

B

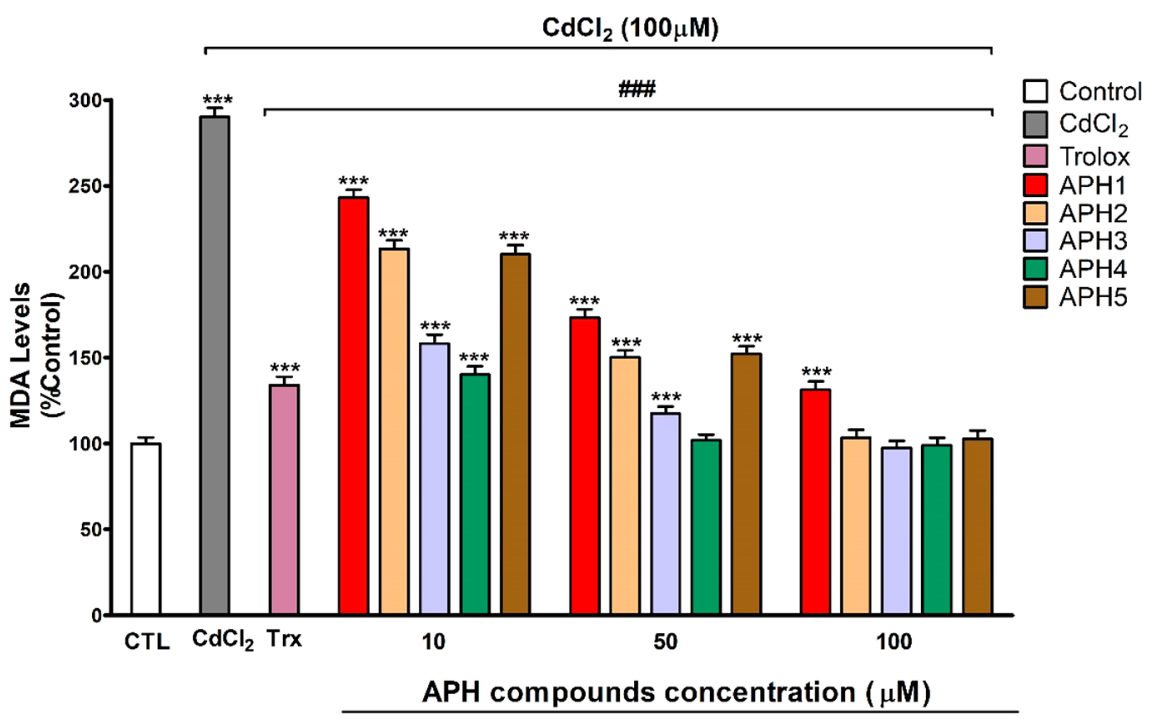

Figure 9. Neuroprotective action of selected APH compounds against lipid peroxidation induced by $\mathrm{FeCl}_{2}$ and $\mathrm{CdCl}_{2}$ metals in $\mathrm{SN} 56$ cells was measured by MDA assay. (A) MDA content after $\mathrm{FeCl}_{2}$ treatment with or without APH compounds. (B) MDA content after $\mathrm{CdCl}_{2}$ treatment with or without APH compounds. Values are given as mean \pm SEM of three separate experiments from cells of different cultures, each one performed in triplicate and presented as percent untreated control. ${ }^{* * *} p \leq 0.001$ compared to control; ${ }^{\# \# \#} p \leq 0.001$ compared to metal treatment.

Further studies are needed to determine the mechanism through which APH compounds mediate the Keap1 and Nrf2 gene expression alteration.

We previously described that APH compounds present antioxidant activity against ROS-induced lipid peroxidation. ${ }^{17}$ In the present study, we show that this action is mediated through the induction of Nrf2 pathway, but we cannot discard other mechanisms are involved. Besides, the greater effect on Keap1, Nrf2, Gpx, and Cat expression was mediated by compound APH4 (Figures 7 and 8), which is correlated with the higher antioxidant effect observed for this compound, ${ }^{17}$ supporting our results.

Antioxidant Activity of Compounds APH1-APH5 against Metal-Induced Lipid Peroxidation. The heavy $\left(\mathrm{CdCl}_{2}\right)$ and essential $\left(\mathrm{FeCl}_{2}\right)$ metals generation of malondialdehyde (MDA) was determined as a marker of oxidative stress damage induced by metals. MDA, a product of the ROSpromoted degradation of arachidonic acid, is the best-known lipid peroxidation marker. Obtained results show that both metals induced lipid peroxidation at the concentrations used (Figure 9a,b). Concentrations used were selected because they were the ones that produce cell damage (data no shown). Several in vitro studies reported that $\mathrm{FeCl}_{2}$ and $\mathrm{CdCl}_{2}$ induced, at these concentrations, oxidative stress and cell death, ${ }^{8,41,42}$ supporting our results.

Treatment of SN56 cells with APH compounds alone did not produce any effect on MDA levels (data not shown). Pretreatment with the antioxidant trolox at $100 \mu \mathrm{M}$ concentration prevented partially the lipid peroxidation induced by cadmium and iron (Figure 9a,b). Pretreatment with compounds APH1, AHP2, APH3, APH4, or APH5, prior to heavy or essential metal treatment, averted lipid peroxidation in a concentration-dependent way, starting from the $10 \mu \mathrm{M}$ concentration (Figure 9a,b). This protection was complete after pretreatment with APH4 compound at $50 \mu \mathrm{M}$ concentration in both metals (Figure 9a,b). Finally, pretreatment with compounds APH2, APH3, or APH5, at $100 \mu \mathrm{M}$ concentration, the same one used for trolox, protected 
completely against the lipid peroxidation induced by both metals (Figure 9a,b). Thus, compounds APH2-APH5 are more potent than trolox. These data support the antioxidant effect of these compounds not only after $\mathrm{H}_{2} \mathrm{O}_{2}$ insults as previously shown ${ }^{17}$ but also against all insults induced by ROS generated after metals exposure.

Otherwise, the compound APH4 was not able to protect completely against the cell damage induced by any metal at the concentration of $50 \mu \mathrm{M}$ (Figures 5 and 6). However, it was able to avoid completely the oxidative stress induced by $\mathrm{FeCl}_{2}$ and $\mathrm{CdCl}_{2}$ (Figure 9a,b). Besides, the compounds APH3, APH4, and APH5, at the concentration of $100 \mu \mathrm{M}$, were not able to completely protect against the cell damage induced by $\mathrm{FeCl}_{2}$ (Figure 5a), but they prevented completely the oxidative stress induced by this metal (Figure 9a). These facts indicate that, besides the oxidative stress, additional mechanisms should be involved in the cytotoxicity of these metals. It also suggests that, in addition to the antioxidant effect of these compounds, they mediate their neuroprotective effect by other mechanisms, probably different than MMPs inhibition or the chelating activity depending of the metal. These metals were reported to induce the accumulation and aggregation of amyloid proteins leading to cell death. ${ }^{1-3}$ Moreover, these metals were related with the alteration of $\mathrm{Wnt} / \beta$-catenin pathway and glutamatergic system and the induction of neuroinflammation, producing neurodegeneration. $^{1-3,43,44}$ Studies to elucidate the neuroprotective mechanisms of APH compounds, besides of those commented already, have not been previously performed. However, the parent compound $6(5 \mathrm{H})$-phenanthridinone was described to present poly(ADP-ribose)polymerase (PARP) inhibitor activity. ${ }^{45}$ PARP was involved in inflammation induction. Its inhibition produces anti-inflammatory effects, ${ }^{46}$ and it was also observed that its inhibition increases the NRF2 nuclear and cytosolic levels in rat retinal cells injured by chronic hypoxia/reoxygenation process. $^{47}$ Thus, AHP1APH5 compounds could mediate their antioxidant effects as well as other neuroprotective mechanisms through PARP inhibition. Besides, phenanthridin-6(5H)-one derivatives were also shown to act as $\mathrm{Wnt} / \beta$-catenin signaling pathway agonists. $^{48}$ Additionally, $\mathrm{Wnt} / \beta$-catenin signaling pathway activation was reported to possibly induce the NFR2 expression through GSK-3 $\beta$ inhibition. ${ }^{49}$ Therefore, APH compounds could also block these cytotoxic actions through these mechanisms, contributing together with the antioxidant, chelating, and MMPs inhibition activities to the neuroprotective effects observed against the neurotoxic action of these metals. Further studies are required to determine the rest of the neuroprotective mechanisms of these multitarget compounds that could be used in the treatment of different neurodegenerative diseases.

\section{CONCLUSIONS}

To summarize, all compounds APH1-APH5 were able to chelate iron and copper ions. Moreover, APH3, APH4, and APH5 were also able to chelate mercury ions. Nevertheless, none of the APH compounds was able to chelate zinc, cadmium, and aluminum. The cytotoxic effects induced by all studied metals were prevented completely or partially depending on the compound used, with the most promising compound APH4. However, it is necessary to corroborate the neuroprotection action in vivo and against other toxic stimuli to confirm APH4 compound as the best APH therapeutic tool.
Otherwise, the antioxidant effect of the evaluated compounds is mediated through induction of the Nrf2 pathway that leads to overexpression of antioxidant enzymes. Further studies are required to survey the rest of the possible mechanisms involved in the neuroprotective effect of these compounds.

Consequently, the relevance of our results lies in finding the chelating, antioxidant, and neuroprotective properties of new multitarget 7 -aminophenanthridin-6(5H)-one derivatives that could help improve the treatment management of different neurodegenerative diseases.

\section{METHODS}

General Experimental Information. All reagents were purchased from Sigma-Aldrich and Fluka (Madrid, Spain), and solvents from SDS (Madrid, Spain) were of commercial quality and were used as received. Reactions were monitored by thin-layer chromatography, $0.20 \mathrm{~mm}$ silica gel 60 F254 plates (Merck, Madrid, Spain) with fluorescent indicator (SDS CCM221254), and then visualized with an ultraviolet (UV) lamp. Separations by flash chromatography were performed on silica gel (SDS 60 ACC 15 40-63 $\mu \mathrm{m}$ ). Infrared spectra were recorded on a PerkinElmer Paragon 1000 FT-IR spectrophotometer (PerkinElmer, Madrid, Spain). NMR spectra were obtained on a Bruker Avance 250 spectrometer working at $250 \mathrm{MHz}$ for ${ }^{1} \mathrm{H}$ and $63 \mathrm{MHz}$ for ${ }^{13} \mathrm{C}$ and operated via the standard Bruker software (Nuclear Magnetic Resonance, Centre for Research Assistance, Complutense University, Madrid, Spain). Chemical shifts are reported in parts per millions relative to tetramethylsilane, and spin multiplicities are given as $\mathrm{s}$ (singlet), $\mathrm{d}$ (doublet), $\mathrm{t}$ (triplet), $\mathrm{q}$ (quartet), or m (multiplet).

General Synthesis Procedure for the Target APH Compounds. Synthesis of 1. A solution of ethyl acetoacetate (3 mmol, 1 equiv) and the suitable primary amine (3-3.9 mmol, $1-1.3$ equiv) in ethanol $(5 \mathrm{~mL})$ was added to cerium(IV) ammonium nitrate $(5 \mathrm{~mol})$ and was stirred for $30 \mathrm{~min}$ at room temperature. Then, appropriate ortho-nitrochalcone (2.4-3.6 mmol, $0.8-1.2$ equiv) was added to the stirred solution, and the mixture was heated to $80^{\circ} \mathrm{C}$ overnight. The reaction mixture was dissolved in ethyl acetate $(30 \mathrm{~mL})$ and washed consecutively with water and brine, and the organic layer was dried with anhydrous $\mathrm{Na}_{2} \mathrm{SO}_{4}$. The solvent was removed under reduced pressure, and the solid was purified by flash column chromatography on silica gel, eluting with a petroleum ether and ethyl acetate mixture $(9: 1, \mathrm{v} / \mathrm{v})$. Compounds 1 were reported in the literature, and their characterization data were identical to those previously described. ${ }^{17}$

Synthesis of 2. A solution of appropriate dihydroantranilate $\mathbf{1}$ (1.5 $\mathrm{mmol}$ ) and DDQ (1.5 equiv) in $10 \mathrm{~mL}$ of toluene was stirred (10 $\mathrm{mL}$ ) for $2 \mathrm{~h}$ at room temperature. Then, the reaction mixture was extracted with ethyl acetate $(30 \mathrm{~mL} \times 3)$, and the combined organic phase was washed with $30 \mathrm{~mL}$ water and $30 \mathrm{~mL}$ brine solution. The residue was concentrated under vacuum, and the crude was purified by flash chromatography on silica gel with a petroleum ether and ethyl acetate gradient (from $9 / 1$ to $8 / 2$ ). Compounds 2 were reported in the literature, and their characterization data were identical to those previously described. ${ }^{17}$

Synthesis of $\mathbf{A P H}$. A solution of appropriate meta-terphenyl compound $2(1 \mathrm{mmol})$ was dissolved in ethanol $(25 \mathrm{~mL})$, and $10 \%$ palladium on carbon $(\mathrm{Pd} / \mathrm{C})(0.1 \mathrm{mmol}, 10 \mathrm{~mol} \%)$ was added. The suspension was stirred at room temperature for $14 \mathrm{~h}$ under hydrogen atmosphere, the catalyst was removed by filtration over Celite and washed with dichloromethane, and the solvent evaporated. The crude was purified by column chromatography on silica gel, eluting with a petroleum ether-ethyl acetate gradient (from 8:2 to 1:1). Compounds APH were reported in the literature, and their characterization data were identical to those previously described. ${ }^{17}$

7-(Butylamino)-9-phenylphenanthridin-6(5H)-one (APH1). ${ }^{1} \mathrm{H}$ NMR $\left(250 \mathrm{MHz}\right.$, DMSO-d $\left.d_{6}\right) \delta 9.46(\mathrm{t}, J=4.9 \mathrm{~Hz}, 1 \mathrm{H}), 8.42(\mathrm{~d}, J$ $=7.9 \mathrm{~Hz}, 1 \mathrm{H}), 7.86(\mathrm{~d}, J=6.9 \mathrm{~Hz}, 2 \mathrm{H}), 7.74(\mathrm{~s}, 1 \mathrm{H}), 7.57-7.40(\mathrm{~m}$, $4 \mathrm{H}), 7.31(\mathrm{~d}, J=7.1 \mathrm{~Hz}, 1 \mathrm{H}), 7.21(\mathrm{t}, J=7.5 \mathrm{~Hz}, 1 \mathrm{H}), 6.88(\mathrm{~s}, 1 \mathrm{H})$, 
$3.31-3.24(\mathrm{~m}, 2 \mathrm{H}), 1.75-1.61(\mathrm{~m}, 2 \mathrm{H}), 1.56-1.38(\mathrm{~m}, 2 \mathrm{H}), 0.96(\mathrm{t}$, $J=7.3 \mathrm{~Hz}, 3 \mathrm{H})$.

7-((4-Methoxyphenyl)amino)-9-phenylphenanthridin-6(5H)-one (APH2). ${ }^{1} \mathrm{H}$ NMR $\left(250 \mathrm{MHz}, \mathrm{CDCl}_{3}\right) \delta 10.93(\mathrm{~s}, 1 \mathrm{H}), 9.20(\mathrm{~s}, 1 \mathrm{H})$, $8.27(\mathrm{~d}, J=7.8 \mathrm{~Hz}, 1 \mathrm{H}), 7.73(\mathrm{~d}, J=1.3 \mathrm{~Hz}, 1 \mathrm{H}), 7.63(\mathrm{dd}, J=8.1$, $1.5 \mathrm{~Hz}, 2 \mathrm{H}), 7.52-7.40(\mathrm{~m}, 4 \mathrm{H}), 7.33-7.27(\mathrm{~m}, 3 \mathrm{H}), 7.26(\mathrm{~d}, J=1.4$ $\mathrm{Hz}, 1 \mathrm{H}), 7.18$ (d, $J=7.9 \mathrm{~Hz}, 1 \mathrm{H}), 6.99(\mathrm{~d}, J=8.9 \mathrm{~Hz}, 2 \mathrm{H}), 3.88$ (s, $3 \mathrm{H})$.

7-((4-Dimethylaminophenyl)amino)-9-phenylphenanthridin6(5H)-one (APH3). ${ }^{1} \mathrm{H}$ NMR $\left(250 \mathrm{MHz}, \mathrm{DMSO}-d_{6}\right) \delta 8.46(\mathrm{~d}, J=$ $8.1 \mathrm{~Hz}, 1 \mathrm{H}), 7.84(\mathrm{~s}, 1 \mathrm{H}), 7.68(\mathrm{~d}, J=6.9 \mathrm{~Hz}, 2 \mathrm{H}), 7.59-7.42(\mathrm{~m}$, $5 \mathrm{H}), 7.42-7.32(\mathrm{~m}, 2 \mathrm{H}), 7.29-7.17(\mathrm{~m}, 3 \mathrm{H}), 7.11(\mathrm{~s}, 1 \mathrm{H}), 6.80(\mathrm{~d}, J$ $=8.9 \mathrm{~Hz}, 2 \mathrm{H}), 2.91(\mathrm{~s}, 5 \mathrm{H})$.

7-((4-Methoxyphenyl)amino)-9-(thiophen-2-yl)phenanthridin6(5H)-one (APH4). ${ }^{1} \mathrm{H}$ NMR (250 MHz, DMSO-d $\left.d_{6}\right) \delta 11.62(\mathrm{~s}, 1 \mathrm{H})$, $11.19(\mathrm{~s}, 1 \mathrm{H}), 8.46(\mathrm{~d}, J=7.9 \mathrm{~Hz}, 1 \mathrm{H}), 7.94(\mathrm{~s}, J=1.0 \mathrm{~Hz}, 1 \mathrm{H}), 7.74$ $(\mathrm{dd}, J=3.7,1.0 \mathrm{~Hz}, 1 \mathrm{H}), 7.62(\mathrm{dd}, J=5.0,1.0 \mathrm{~Hz}, 1 \mathrm{H}), 7.50(\mathrm{t}, J=$ $8.1 \mathrm{~Hz}, 1 \mathrm{H}), 7.38-7.23(\mathrm{~m}, 4 \mathrm{H}), 7.21-7.14(\mathrm{~m}, 2 \mathrm{H}), 7.02(\mathrm{~d}, J=8.9$ $\mathrm{Hz}, 2 \mathrm{H}), 3.79$ (s, 3H).

7-(Phenylamino)-9-(thiophen-2-yl)phenanthridin-6(5H)-one (APH5). ${ }^{1} \mathrm{H}$ NMR $\left(250 \mathrm{MHz}, \mathrm{DMSO}-d_{6}\right) \delta 11.35(\mathrm{~d}, J=9.0 \mathrm{~Hz}, 2 \mathrm{H})$, $8.64(\mathrm{~d}, J=8.1 \mathrm{~Hz}, 1 \mathrm{H}), 8.12(\mathrm{~d}, J=1.6 \mathrm{~Hz}, 1 \mathrm{H}), 7.84(\mathrm{dd}, J=3.7$, $1.2 \mathrm{~Hz}, 1 \mathrm{H}), 7.77(\mathrm{~d}, J=8.3 \mathrm{~Hz}, 1 \mathrm{H}), 7.72-7.63(\mathrm{~m}, 2 \mathrm{H}), 7.52-7.45$ (m, 2H), 7.45-7.37 (m, 3H), 7.29-7.08 (m, 2H).

Metal-Chelating Study. The chelating studies were performed with a diode array HP8543 UV-vis spectrophotometer (Agilent Technologies), by using a $1.0 \mathrm{~cm}$ quartz cuvette and the HP Chemstation software. The absorption spectra were collected at room temperature. Absorbance measurements of the tested compounds alone or in the presence of $\mathrm{FeCl}_{2}, \mathrm{CuCl}_{2}, \mathrm{HgCl}_{2}, \mathrm{ZnCl}_{2}, \mathrm{CdCl}_{2}$, or $\mathrm{AlCl}_{3}$ were carried out in $100 \mathrm{mM}$ phosphate buffer solution at $\mathrm{pH}$ 7.30 and registered within the $200-600 \mathrm{~nm}$ range. In all cases, blank solutions were properly analyzed.

Stock solutions of $\mathrm{Fe}^{2+}, \mathrm{Cu}^{2+}, \mathrm{Hg}^{2+}, \mathrm{Zn}^{2+}, \mathrm{Cd}^{2+}$, and $\mathrm{Al}^{3+}(2.5 \mathrm{mM}$, final concentration) were prepared in Milli- $\mathrm{Q}$ water. The metal solutions were stirred until complete dissolution by using an ultrasound probe (Vibracell Sonics), equipped with a $2 \mathrm{~mm}$ diameter titanium microtip, at $60 \%$ power width during $2 \mathrm{~min}$. Evaluated compounds were dissolved in an aqueous mixture of DMSO $100 \mathrm{mM}$ phosphate buffer $\mathrm{pH}=7.30$ at ratios $1: 2 \mathrm{v} / \mathrm{v}(0.50 \mathrm{mM}$, final concentration) and $1: 14 \mathrm{v} / \mathrm{v}(0.10 \mathrm{mM}$, final concentration) by employing an ultrasonic bath for $10 \mathrm{~min}$. Working solutions of compounds alone and compound-metal complexes were daily prepared by dilution of stock solutions in buffer as required.

Chelation was detected as a consequence of the changes observed in the absorption spectra after $30 \mathrm{~min}$ of incubation. With the aim of estimating the stoichiometry of the compound-metal complexes, a fixed amount of APH1, AHP2, APH3, APH4, or APH5 compounds $(50 \mu \mathrm{M})$ was mixed with increasing amounts of metal ion (6.25-50 $\mu \mathrm{M})$. Similarly, a fixed amount of metal $(50 \mu \mathrm{M})$ was mixed with increasing amounts of APH1, AHP2, APH3, APH4, or APH5 compounds to achieve compound concentrations from 50 to $200 \mu \mathrm{M}$. UV-vis spectra were carefully examined in order to evaluate absorption differences and to estimate the ratio metal/compound in the formed complexes. Derivative spectroscopy was also applied to resolve stoichiometry studies.

HOMO and LUMO Analysis. The ability of a molecule to form complexes can be examined by the molecular orbital frontier approach. This approach is based on the premise that electrons are transferred from the HOMO orbital to the LUMO orbital in the formation of new bonds between the atoms. Thus, HOMO orbital indicates the ability to donate electrons, the LUMO orbitals show the ability to accept electrons of a molecule, and the greater the energy gap is between these HOMO/LUMO orbitals, the higher the molecule polarizability is, which is usually translated into a higher chemical reactivity. ${ }^{50}$

Molecular modeling was performed with ChemBio3D software (version 14.0 ultra), and HOMO and LUMO levels were researched using molecular mechanics (MM2) and MMFF94 force field analysis. For the optimized structure, HOMO-LUMO energies were analyzed.
Physicochemical and Prediction of ADMET Properties Analysis. In silico assessment of relevant drug-likeness properties and a series of ADMET properties was carried out using ADMETsar version 2.0 (http://lmmd.ecust.edu.cn/admetsar2) and SwissADME; S (http://www.swissadme.ch/) software. ${ }^{51,52}$ We calculated the most significant physicochemical properties required for absorption into the central nervous system such as the molecular weight and octanolwater partition coefficient $(\log P)$, as other parameters in association with Lipinski's rule of five and the suitability of a drug molecule for oral administration such as $\mathrm{H}$-bond acceptors and H-bond donors. ${ }^{53}$

Culture of SN56 Cells. The protection induced by APH compounds against metals toxic effects was evaluated using a cholinergic murine neuroblastoma cell line (SN56 cells) derived from the basal forebrain septum. Basal forebrain contains the majority of CNS cholinergic neurons, ${ }^{54}$ which innervate the hippocampus and frontal cortex, regulating learning and memory process. ${ }^{55,56}$ Their selective degeneration, as observed in $\mathrm{AD}$ and other neurodegenerative diseases, induced cognitive dysfunction. ${ }^{57,58}$ We chose this cells line since the essential and heavy metals brain accumulation was related with memory and learning alterations, ${ }^{1-3}$ with some of them reported to induce a more pronounced damage in basal forebrain cholinergic neurons, ${ }^{8,59}$ so it is a sensitive model to study their toxic effects. Dulbecco's modified Eagle's medium (DMEM) supplemented with $10 \%$ fetal bovine serum, penicillin/streptomycin, 2 $\mathrm{mM}$ L-glutamine (Sigma, Madrid, Spain), and $1 \mathrm{mM}$ sodium pyruvate was used to maintain cells at $37{ }^{\circ} \mathrm{C}$ and $5 \% \mathrm{CO}_{2}$. This medium was changed every $48 \mathrm{~h} .{ }^{60}$ Cells were differentiated via culture for 3 days with $1 \mathrm{mM}$ dibutyryl-cAMP and $1 \mu \mathrm{M}$ retinoic acid. ${ }^{61,62}$ Following cells differentiation, there were no differences in cells regarding the periods of treatment. All cells used in these studies showed to be mycoplasma-free using the Look Out Mycoplasma PCR Detection Kit (Sigma, Madrid, Spain).

Cells were seeded in 6-well plates at a density of $10^{6}$ cells/well. To determine APH compounds neuroprotective effects against $\mathrm{FeCl}_{2}$ $(200 \mu \mathrm{M}), \mathrm{CuCl}_{2}(20 \mu \mathrm{M}), \mathrm{ZnCl}_{2}(250 \mu \mathrm{M}), \mathrm{CdCl}_{2}(100 \mu \mathrm{M})$, $\mathrm{HgCl}_{2}(30 \mu \mathrm{M})$, and $\mathrm{AlCl}_{3}(300 \mu \mathrm{M})$ cytotoxic effects, cells were treated with the APH1, AHP2, APH3, APH4, or APH5 compounds in concentrations between 10 and $100 \mu \mathrm{M}$ and with trolox at $100 \mu \mathrm{M}$ concentration. Besides, to determine the antioxidant mechanisms of APH1, AHP2, APH3, APH4, and APH5 compounds, cells were treated for $24 \mathrm{~h}$ with them in concentrations between 10 and $100 \mu \mathrm{M}$. At least three replicate wells/treatment were used. A vehicle group was employed in parallel for each experiment as a control.

APH1-APH5 compounds were selected because they were the APH compounds with less cytotoxic effects and because they presented the most potent antioxidant and neuroprotective effect against ROS stimulus. ${ }^{17}$ The range of $10-100 \mu \mathrm{M}$ concentrations was chosen because it is a range of concentrations without cytotoxicity in which it is more probable that their neuroprotective effects are developed. The concentrations of metals used were selected because they were observed to induce cell death (data not shown). The metals used were selected because they were reported to induce neurodegeneration and were mainly associated with neurodegenerative disese. $^{1-3}$

Cytotoxic and Neuroprotective Effect on SN56 Cells. The 3(4,5-dimethylthiazol-2-yl)-2,5-diphenyltetrazolium bromide (MTT) assay, which is based on the cleavage of the yellow tetrazolium salt MTT to purple formazan crystals by mitochondrial dehydrogenase, was used to evaluate SN56 cells viability. The cytotoxic effects of metals on SN56 cells were determined after incubation for $24 \mathrm{~h}$ with $\mathrm{FeCl}_{2}(200 \mu \mathrm{M}), \mathrm{CuCl}_{2}(20 \mu \mathrm{M}), \mathrm{ZnCl}_{2}(250 \mu \mathrm{M}), \mathrm{CdCl}_{2}(100 \mu \mathrm{M})$, $\mathrm{HgCl}_{2}(30 \mu \mathrm{M})$, and $\mathrm{AlCl}_{3}(300 \mu \mathrm{M})$. The metal concentrations used were previously tested and observed to induce cell death (data not shown). The neuroprotective effects of compounds APH1, AHP2, APH3, APH4, and APH5 against these metals were evaluated after incubation for $24 \mathrm{~h}$ with $\mathrm{FeCl}_{2}(200 \mu \mathrm{M}), \mathrm{CuCl}_{2}(20 \mu \mathrm{M}), \mathrm{ZnCl}_{2}$ $(250 \mu \mathrm{M}), \mathrm{CdCl}_{2}(100 \mu \mathrm{M}), \mathrm{HgCl}_{2}(30 \mu \mathrm{M})$, and $\mathrm{AlCl}_{3}(300 \mu \mathrm{M})$ of SN56 cells pretreated with compounds 4 at various concentrations $(10-100 \mu \mathrm{M})$ for $2 \mathrm{~h}$. 
At the end of the assays, cells were incubated with $100 \mu \mathrm{L}$ of yellow MTT solution (final concentration $0.5 \mathrm{mg} / \mathrm{mL}$ ) for $4 \mathrm{~h}$. After $4 \mathrm{~h}$ at $37{ }^{\circ} \mathrm{C}$, the medium was removed, and $150 \mu \mathrm{L}$ DMSO was used to dissolve the formazan reaction product. The formation of solubilized formazan product was measured spectrophotometrically at $570 \mathrm{~nm}$ (Fluoroskan Ascent FL Microplate Fluorometer and Luminometer, Thermo Fisher Scientific, Madrid, Spain). Control cells were taken as $100 \%$ viability.

Real-Time PCR Analysis. The Trizol reagent method (Invitrogen, Madrid, Spain) was used to extract total RNA. A Nanodrop 2000 (Thermo Fisher Scientific, Madrid, Spain) spectrophotometer and an Experion Lab Chip (Bio-Rad, Madrid, Spain) gel were used to determine the final RNA concentration and assess the quality of total RNA samples, respectively. We synthesized the first strand cDNA using a PCR array first strand-synthesis kit (C-02; Super Array Bioscience, Madrid, Spain) with $1000 \mathrm{ng}$ of cRNA, following the manufacturer's instructions, with an added genomic DNA elimination step and external RNA controls. Following reverse transcription, QPCR was performed using prevalidated primer sets (SuperArray Bioscience) for mRNAs encoding Keap1 (PPM34919B), Nrf2 (PPM24614A), Cat (PPM04394C), Gpx (PPM04345E), and Actb (PPM02945B). Actb was used as an internal control for normalization. A CFX96 was used to run reactions with real-time SYBR green PCR master mix PA-012 (SuperArray Bioscience). The thermocycler parameters were established as $95{ }^{\circ} \mathrm{C}$ for $10 \mathrm{~min}$, followed by 40 cycles of $95{ }^{\circ} \mathrm{C}$ for $15 \mathrm{~s}$ and $72{ }^{\circ} \mathrm{C}$ for $30 \mathrm{~s}$. We used the $\mathrm{Ct}$ (cycle threshold) method to calculate relative changes in gene expression. The expression data are presented as actual change multiples. ${ }^{63}$

Protein Expression Analysis. Treated cells were washed with cold PBS, scraped, and harvested. Then, harvested cells were lysed using radioimmunoprecipitation assay (RIPA) reagent (Thermo Fisher, Madrid, Spain) with a protease repressors mixture (Thermo Fisher, Madrid, Spain), following the manufacturer's protocol. Finally, cell lysates were centrifuged at $10,000 \mathrm{~g}$ during $10 \mathrm{~min}$ at $4{ }^{\circ} \mathrm{C}$, and the supernatant was collected. Total protein levels were assayed with a bicinchoninic acid (BCA) assay kit (catalog number 23225; ThermoFisher, Madrid, Spain), according to manufacturer's guideline.

Keap1, Nrf2, Gpx, and Cat protein expression was determined employing commercial ELISA tests in cell lysate supernatant (catalog numbers MBS7212746, MBS776676, MBS732750, and MBS728474, respectively; MyBiosource, CA, USA) in accordance with producer's protocols. The protein concentrations of each target gene were normalized with the total protein levels measured by BCA kit, to prevent possible interferences with the real value of the targets' protein concentrations measured due to the induction of cell death. Protein levels were expressed in $\mathrm{ng} / \mathrm{mg}$ protein.

Protective Effects on Cell Lipid Peroxidation. MDA concentration was determined as an indicator of lipid peroxidation products induced by free radicals. Intracellular MDA production was quantified after $24 \mathrm{~h}$ exposure to $\mathrm{FeCl}_{2}(200 \mu \mathrm{M})$ or $\mathrm{CdCl}_{2}(100 \mu \mathrm{M})$ with or without APH1, AHP2, APH3, APH4, or APH5 compounds (10-100 $\mu \mathrm{M})$, using a Lipid Peroxidation MDA Assay Kit (Abcam, Cambridge, UK), following the manufacturer's protocol. Briefly, following treatment, we collected $1 \times 10^{6}$ cells and homogenized them on ice in MDA lysis buffer $(300 \mu \mathrm{L})$ with $3 \mu \mathrm{L}$ BHT $(100 \times)$. Then, the mix was centrifuged for $10 \mathrm{~min}$ at $13,000 \mathrm{~g}$ to remove insoluble material. Sample $(200 \mu \mathrm{L})$ or standard $(200 \mu \mathrm{L}$ of MDA $)$ was mixed with $600 \mu \mathrm{L}$ of thiobarbituric acid solution, incubated at 95 ${ }^{\circ} \mathrm{C}$ for $50 \mathrm{~min}$, and cooled to room temperature in an ice bath for 10 min. We loaded all samples and standards $(200 \mu \mathrm{L})$ (duplicate) into a clear 96-well plate, and a microplate reader (Fluoroskan Ascent FL Microplate Fluorometer and Luminometer, Thermo Fisher Scientific, Madrid, Spain) was used to record the absorbance at $532 \mathrm{~nm}$. Concentration of MDA, determined as $\mathrm{nmol} / \mathrm{mg}$ protein, is presented as percent untreated control.

Statistical Analysis. At least three replicates for each experimental condition were performed, and the presented results were representative of these replicates. Data are presented as means \pm standard error of the mean. Comparisons between experimental and control groups were performed by two-ways ANOVA analyses (concentration vs treatment) or one-way ANOVA analyses (analysis of different 7-aminophenanthridin compounds concentrations) followed by the Tukey posthoc test. Statistical difference was accepted when $p \leq 0.05$. Statistical analysis of data was carried out using GraphPad Prism 5.01 software.

\section{ASSOCIATED CONTENT}

\section{(s) Supporting Information}

The Supporting Information is available free of charge at https://pubs.acs.org/doi/10.1021/acschemneuro.1c00333.

Figures showing optimized molecular structure of APH1-APH3 and APH5, their iron complex and their corresponding HOMOs and LUMOs; cell viability effects after APH1-APH5 treatment; and APH1APH5 UV-vis spectra and first-order derivative absorption spectra, alone and in the presence of metals. Tables with results of HOMO/LUMO gap energy analysis and $\mathrm{ADMET}$ prediction of $\mathrm{APH}$ compounds (PDF)

\section{AUTHOR INFORMATION}

\section{Corresponding Authors}

Juan F. González - Unidad de Química Orgánica y Farmacéutica, Departamento de Química en Ciencias Farmacéuticas, Facultad de Farmacia, Universidad Complutense, 28040 Madrid, Spain; Email: jfgonzal@ ucm.es

Noelia Rosales-Conrado - Departamento de Química Analítica, Facultad de Ciencias Químicas, Universidad Complutense, 28040 Madrid, Spain; Email: nrosales@ ucm.es

Javier del Pino - Departamento de Farmacología y Toxicología, Facultad de Veterinaria, Universidad Complutense, 28040 Madrid, Spain; 이이.org/0000-

0001-6937-7701; Email: jdelpino@pdi.ucm.es

\section{Authors}

Paula Moyano - Departamento de Farmacología y Toxicología, Facultad de Veterinaria, Universidad Complutense, 28040 Madrid, Spain

David Vicente-Zurdo - Departamento de Química Analítica, Facultad de Ciencias Químicas, Universidad Complutense, 28040 Madrid, Spain

Cristina Blázquez-Barbadillo - Unidad de Química Orgánica y Farmacéutica, Departamento de Química en Ciencias Farmacéuticas, Facultad de Farmacia, Universidad Complutense, 28040 Madrid, Spain

J. Carlos Menéndez - Unidad de Química Orgánica y Farmacéutica, Departamento de Química en Ciencias Farmacéuticas, Facultad de Farmacia, Universidad Complutense, 28040 Madrid, Spain; ○ orcid.org/00000002-0560-8416

Complete contact information is available at: https://pubs.acs.org/10.1021/acschemneuro.1c00333

\section{Author Contributions}

"These authors contributed equally.

\section{Funding}

This research was supported by the following grants: CTQ2015-68380-R and RTI2018-097662-B-I00 (from MICINN) to J.C.M. and PR26/16-16B (from UCM) to J.F.G., J.P., and N.R.C. 


\section{Notes}

The authors declare no competing financial interest.

\section{ACKNOWLEDGMENTS}

We gratefully acknowledge MINECO, MICINN, and UCM for financial support of this research.

\section{ABBREVIATIONS}

$\mathrm{AD}$, Alzheimer's disease; ADMET, absorption, distribution, metabolism, excretion, and toxicological properties; ALS, amyotrophic lateral sclerosis; ANOVA, analysis of variance; $\mathrm{APH}$, 7-amino-phenanthridin-6-one derivatives; $\mathrm{BBB}$, bloodbrain barrier; BHT, butylated hydroxytoluene; CNS, central nervous system; DDQ, 2,3-dichloro-5,6-dicyano-1,4-benzoquinone; DMEM, Dulbecco's modified Eagle's medium; DMSO, dimethyl sulfoxide; HD, Huntington's disease; HOMO, Highest occupied molecular orbital; KEAP1, Kelch-like ECH-associated protein 1; LUMO, Lowest unoccupied molecular orbital; MDA, malondialdehyde; MMP, matrix metalloproteinase; MMFF94, Merck molecular force field 94; MM2, molecular mechanics force field; MTT, 3-(4,5dimethylthiazol-2-yl)-2,5-diphenyltetrazolium; NRF2, nuclear factor erythroid 2-related factor 2; PARP-1, poly(ADP-ribose) polymerase-1; PD, Parkinson's disease; p-tau, tau-phosphorylated; ROS, reactive oxygen species; UV-vis, ultravioletvisible spectroscopy

\section{REFERENCES}

(1) Cannon, J. R.; Greenamyre, J. T. The role of environmental exposures in neurodegeneration and neurodegenerative diseases. Toxicol. Sci. 2011, 124 (2), 225.

(2) Chin-Chan, M.; Navarro-Yepes, J.; Quintanilla-Vega, B. Environmental pollutants as risk factors for neurodegenerative disorders: Alzheimer and Parkinson diseases. Front. Cell. Neurosci. 2015, 9, 124.

(3) Mir, R. H.; Sawhney, G.; Pottoo, F. H.; Mohi-Ud-Din, R.; Madishetti, S.; Jachak, S. M.; Ahmed, Z.; Masoodi, M. H. Role of environmental pollutants in Alzheimer's disease: a review. Environ. Sci. Pollut. Res. 2020, 27 (36), 44724.

(4) Chen, P.; Miah, M. R.; Aschner, M. Metals and Neurodegeneration. F1000Research 2016, 5, 366.

(5) Gozzelino, R.; Arosio, P. Iron Homeostasis in Health and Disease. Int. J. Mol. Sci. 2016, 17 (1), 130.

(6) Zheng, W.; Monnot, A. D. Regulation of brain iron and copper homeostasis by brain barrier systems: implication in neurodegenerative diseases. Pharmacol. Ther. 2012, 133 (2), 177.

(7) Choi, S.; Hong, D. K.; Choi, B. Y.; Suh, S. W. Zinc in the Brain: Friend or Foe? Int. J. Mol. Sci. 2020, 21 (23), 8941.

(8) Moyano, P.; De Frias, M.; Lobo, M.; Anadon, M. J.; Sola, E.; Pelayo, A.; Díaz, M. J.; Frejo, M. T.; Del Pino, J. Cadmium induced ROS alters M1 and M3 receptors, leading to SN56 cholinergic neuronal loss, through AChE variants disruption. Toxicology 2018, 394, 54.

(9) Brkic, M.; Balusu, S.; Libert, C.; Vandenbroucke, R. E. Friends or foes: matrix metalloproteinases and their multifaceted roles in neurodegenerative diseases. Mediators Inflammation 2015, 2015, 620581.

(10) Dagouassat, M.; Lanone, S.; Boczkowski, J. Interaction of matrix metalloproteinases with pulmonary pollutants. Eur. Respir. J. 2012, 39 (4), 1021.

(11) Rosenberg, G. A. Matrix metalloproteinases and their multiple roles in neurodegenerative diseases. Lancet Neurol. 2009, 8 (2), 205.

(12) Rosenberg, G. A. Metalloproteinases and neurodegenerative diseases: pathophysiological and therapeutic perspectives. Metalloproteinases. Med. 2015, 2015 (2), 39.
(13) Bjerke, M.; Zetterberg, H.; Edman, Å.; Blennow, K.; Wallin, A.; Andreasson, U. Cerebrospinal fluid matrix metalloproteinases and tissue inhibitor of metalloproteinases in combination with subcortical and cortical biomarkers in vascular dementia and Alzheimer's disease. J. Alzheimer's Dis. 2011, 27 (3), 665.

(14) Asahina, M.; Yoshiyama, Y.; Hattori, T. Expression of matrix metalloproteinase-9 and urinary-type plasminogen activator in Alzheimer's disease brain. Clin. Neuropathol. 2001, 20 (2), 60.

(15) Su, X.; Maguire-Zeiss, K. A.; Giuliano, R.; Prifti, L.; Venkatesh, K.; Federoff, H. J. Synuclein activates microglia in a model of Parkinson's disease. Neurobiol. Aging 2008, 29 (11), 1690.

(16) Vandenbroucke, R. E.; Libert, C. Is there new hope for therapeutic matrix metalloproteinase inhibition? Nat. Rev. Drug Discovery 2014, 13 (12), 904.

(17) Rocchi, D.; Blázquez-Barbadillo, C.; Agamennone, M.; Laghezza, A.; Tortorella, P.; Vicente-Zurdo, D.; Rosales-Conrado, N.; Moyano, P.; Pino, J. D.; González, J. F.; Menéndez, J. C. Discovery of 7-aminophenanthridin-6-one as a new scaffold for matrix metalloproteinase inhibitors with multitarget neuroprotective activity. Eur. J. Med. Chem. 2021, 210, 113061.

(18) Li, N.; Alam, J.; Venkatesan, M. I.; Eiguren-Fernandez, A.; Schmitz, D.; Di Stefano, E.; Slaughter, N.; Killeen, E.; Wang, X.; Huang, A.; Wang, M.; Miguel, A. H.; Cho, A.; Sioutas, C.; Nel, A. E. $\mathrm{Nrf2}$ is a key transcription factor that regulates antioxidant defense in macrophages and epithelial cells: protecting against the proinflammatory and oxidizing effects of diesel exhaust chemicals. J. Immunol. 2004, 173 (5), 3467.

(19) Luo, D. D.; Chen, J. F.; Liu, J. J.; Xie, J. H.; Zhang, Z. B.; Gu, J. Y.; Zhuo, J. Y.; Huang, S.; Su, Z. R.; Sun, Z. H. Tetrahydrocurcumin and octahydrocurcumin, the primary and final hydrogenated metabolites of curcumin, possess superior hepatic-protective effect against acetaminophen-induced liver injury: role of CYP2E1 and Keap1-Nrf2 pathway. Food Chem. Toxicol. 2019, 123, 349.

(20) Li, S.; Tan, H.-Y.; Wang, N.; Zhang, Z.-J.; Lao, L.; Wong, C.W.; Feng, Y. The role of oxidative stress and antioxidants in liver diseases. Int. J. Mol. Sci. 2015, 16, 26087.

(21) Osama, A.; Zhang, J.; Yao, J.; Yao, X.; Fang, J. Nrf2: a dark horse in Alzheimer's disease treatment. Ageing Res. Rev. 2020, 64, 101206.

(22) Khan, H.; Tundis, R.; Ullah, H.; Aschner, M.; Belwal, T.; Mirzaei, H.; Akkol, E. K. Flavonoids targeting NRF2 in neurodegenerative disorders. Food Chem. Toxicol. 2020, 146, 111817.

(23) Li, Q.; Xing, S.; Chen, Y.; Liao, Q.; Li, Q.; Liu, Y.; He, S.; Feng, F.; Chen, Y.; Zhang, J.; Liu, W.; Guo, Q.; Sun, Y.; Sun, H. Reasonably activating Nrf2: A long-term, effective and controllable strategy for neurodegenerative diseases. Eur. J. Med. Chem. 2020, 185, 111862.

(24) Suzuki, T.; Hidaka, T.; Kumagai, Y.; Yamamoto, M. Environmental pollutants and the immune response. Nat. Immunol. 2020, 21 (12), 1486.

(25) Iqubal, A.; Ahmed, M.; Ahmad, S.; Sahoo, C. R.; Iqubal, M. K.; Haque, S. E. Environmental neurotoxic pollutants: review. Environ. Sci. Pollut. Res. 2020, 27 (33), 41175.

(26) Zheng, F.; Gonçalves, F. M.; Abiko, Y.; Li, H.; Kumagai, Y.; Aschner, M. Redox toxicology of environmental chemicals causing oxidative stress. Redox Biol. 2020, 34, 101475.

(27) Akbari, G. Role of Zinc Supplementation on Ischemia/ Reperfusion Injury in Various Organs. Biol. Trace Elem. Res. 2020, 196 (1), 1 .

(28) Guerra, W.; Silva-Caldeira, P. P.; Terenzi, H.; Pereira-Maia, E. C. Impact of metal coordination on the antibiotic and non-antibiotic activities of tetracycline-based drugs. Coord. Chem. Rev. 2016, 327$328,188$.

(29) Ř́ha, M.; Karlícková, J.; Filipský, T.; Macáková, K.; Rocha, L.; Bovicelli, P.; Silvestri, I. P.; Saso, L.; Jahodáŕ, L.; Hrdina, R.; Mladěnka, P. In vitro evaluation of copper-chelating properties of flavonoids. RSC Adv. 2014, 4, 32628.

(30) Zheng, J. W.; Ma, L. Metal complexes of anthranilic acid derivatives: A new class of non-competitive $\alpha$-glucosidase inhibitors. Chin. Chem. Lett. 2016, 27 (5), 627. 
(31) Wang, Z.; Wang, Y.; Li, W.; Mao, F.; Sun, Y.; Huang, L.; Li, X. Design, Synthesis, and Evaluation of Multitarget-Directed SeleniumContaining Clioquinol Derivatives for the Treatment of Alzheimer's Disease. ACS Chem. Neurosci. 2014, 5, 952.

(32) Carmona-Vargas, C. C.; Aristizábal, S. L.; Belalcázar, M. I.; D'Vries, R. F.; Chaur, M. N. Determination of the binding constants of propeller-like metal complexes of picolinaldehyde-2-pyridylhydrazone. Inorg. Chim. Acta 2019, 487, 275.

(33) Kılınçarslan, R.; Erdem, E.; Kocaokutgen, H. Synthesis and spectral characterization of some new azo dyes and their metal complexes. Transition Met. Chem. 2007, 32, 102.

(34) Georgieva, S.; Todorov, P.; Bezfamilnyi, A.; Georgiev, A. Coordination behaviour of 3-amino-5,5'-dimethylhydantoin towards $\mathrm{Ni}(\mathrm{II})$ and $\mathrm{Zn}(\mathrm{II})$ ions: Synthesis, spectral characterization and DFT calculations. J. Mol. Struct. 2018, 1166, 377.

(35) Leeson, P. D.; Young, R. J. Molecular Property Design: Does Everyone Get It? ACS Med. Chem. Lett. 2015, 6 (7), 722.

(36) Nguyen, T.; Yang, C. S.; Pickett, C. B. The pathways and molecular mechanisms regulating $\mathrm{Nrf2}$ activation in response to chemical stress. Free Radical Biol. Med. 2004, 37, 433.

(37) Gong, P.; Cederbaum, A. I. Nrf2 is increased by CYP2E1 in rodent liver and HepG2 cells and protects against oxidative stress caused by CYP2E1. Hepatology 2006, 43 (1), 144.

(38) Kabaria, S.; Choi, D. C.; Chaudhuri, A. D.; Jain, M. R.; Li, H.; Junn, E. MicroRNA-7 activates Nrf2 pathway by targeting Keap1 expression. Free Radical Biol. Med. 2015, 89, 548.

(39) Sparaneo, A.; Fabrizio, F. P.; La Torre, A.; Graziano, P.; Di Maio, M.; Fontana, A.; Bisceglia, M.; Rossi, A.; Pizzolitto, S.; De Maglio, G.; Tancredi, A.; Grimaldi, F.; Balsamo, T.; Centra, F.; Manzorra, M. C.; Trombetta, D.; Pantalone, A.; Bonfitto, A.; Maiello, E.; Fazio, V. M.; Muscarella, L. A. Effects of KEAP1 Silencing on the Regulation of NRF2 Activity in Neuroendocrine Lung Tumors. Int. J. Mol. Sci. 2019, 20 (10), 2531.

(40) Padmavathi, G.; Ramkumar, K. M. MicroRNA mediated regulation of the major redox homeostasis switch, Nrf2, and its impact on oxidative stress-induced ischemic/reperfusion injury. Arch. Biochem. Biophys. 2021, 698, 108725.

(41) Bautista, E.; Vergara, P.; Segovia, J. Iron-induced oxidative stress activates AKT and ERK1/2 and decreases Dyrk1B and PRMT1 in neuroblastoma SH-SY5Y cells. J. Trace Elem. Med. Biol. 2016, 34, 62.

(42) Bruce-Keller, A. J.; Li, Y. J.; Lovell, M. A.; Kraemer, P. J.; Gary, D. S.; Brown, R. R.; Markesbery, W. R.; Mattson, M. P. 4Hydroxynonenal, a product of lipid peroxidation, damages cholinergic neurons and impairs visuospatial memory in rats. J. Neuropathol. Exp. Neurol. 1998, 57 (3), 257.

(43) Huat, T. J.; Camats-Perna, J.; Newcombe, E. A.; Valmas, N.; Kitazawa, M.; Medeiros, R. Metal Toxicity Links to Alzheimer's Disease and Neuroinflammation. J. Mol. Biol. 2019, 431 (9), 1843.

(44) Lee, K.; Cao, J.; Lee, C.; Hsiao, T.; Yeh, C.; Huynh, T.; Han, Y.; Li, X.; Chuang, K.; Tian, L.; Ho, K.; Chuang, H. Inhibition of the $\mathrm{WNT} / \beta$-catenin pathway by fine particulate matter in haze: Roles of metals and polycyclic aromatic hydrocarbons. Atmos. Environ. 2015, 109, 118.

(45) Weltin, D.; Picard, V.; Aupeix, K.; Varin, M.; Oth, D.; Marchal, J.; Dufour, P.; Bischoff, P. Immunosuppressive activities of $6(5 \mathrm{H})$ phenanthridinone, a new poly(ADP-ribose)polymerase inhibitor. Int. J. Immunopharmacol. 1995, 17 (4), 265.

(46) Haddad, M.; Rhinn, H.; Bloquel, C.; Coqueran, B.; Szabó, C.; Plotkine, M.; Scherman, D.; Margaill, I. Anti-inflammatory effects of PJ34, a poly(ADP-ribose) polymerase inhibitor, in transient focal cerebral ischemia in mice. Br. J. Pharmacol. 2006, 149, 23.

(47) Kovacs, K.; Vaczy, A.; Fekete, K.; Kovari, P.; Atlasz, T.; Reglodi, D.; Gabriel, R.; Gallyas, F.; Sumegi, B. PARP Inhibitor Protects Against Chronic Hypoxia/Reoxygenation-Induced Retinal Injury by Regulation of MAPKs, $\mathrm{HIF} 1 \alpha, \mathrm{Nrf} 2$, and $\mathrm{NF} \kappa \mathrm{B}$. Invest. Ophthalmol. Visual Sci. 2019, 60 (5), 1478.

(48) Chen, D. Z.; Yang, B. J.; He, X. L.; Fan, S. R.; Cai, J. Y.; Jing, C. X.; Zhang, H.; Zhang, Y.; Li, L.; Hao, X. J. Design, synthesis and structure-activity relationship optimization of phenanthridine derivatives as new Wnt/beta-catenin signalling pathway agonists. Bioorg. Chem. 2019, 84, 285.

(49) Moyano, P.; García, J. M.; García, J.; Pelayo, A.; Muñoz-Calero, P.; Frejo, M. T.; Anadon, M. J.; Naval, M. V.; Flores, A.; Mirat, V. A.; Del Pino, J. Chlorpyrifos induces cell proliferation in MCF-7 and MDA-MB-231 cells, through cholinergic and Wnt $/ \beta$-catenin signaling disruption, AChE-R upregulation and oxidative stress generation after single and repeated treatment. Food Chem. Toxicol. 2021, 152, 112241.

(50) Kumer, A.; Sarker, N.; Paul, S. The simulating study of HOMO, LUMO, thermo physical and quantitative structure of activity relationship (QSAR) of some anticancer active ionic liquids. Eurasian. J. Environ. Res. 2019, 3 (1), 1.

(51) Yang, H.; Lou, C.; Sun, L.; Li, J.; Cai, Y.; Wang, Z.; Li, W.; Liu, G.; Tang, Y. admetSAR 2.0: web-service for prediction and optimization of chemical ADMET properties. Bioinformatics 2019, 35 (6), 1067.

(52) Cheng, F.; Li, W.; Zhou, Y.; Shen, J.; Wu, Z.; Liu, G.; Lee, P. W.; Tang, Y. admetSAR: a comprehensive source and free tool for assessment of chemical ADMET properties. J. Chem. Inf. Model. 2012, 52 (11), 3099.

(53) Lipinski, C. A. Lead- and drug-like compounds: the rule-of-five revolution. Drug Discovery Today: Technol. 2004, 1 (4), 337.

(54) Voytko, M. L. Cognitive functions of the basal forebrain cholinergic system in monkeys: memory or attention? Behav. Brain Res. 1996, 75 (1-2), 13.

(55) Everitt, B. J.; Robbins, T. W. Central cholinergic systems and cognition. Annu. Rev. Psychol. 1997, 48, 649.

(56) Ward, N. L.; Hagg, T. BDNF is needed for postnatal maturation of basal forebrain and neostriatum cholinergic neurons in vivo. Exp. Neurol. 2000, 162 (2), 297.

(57) Scheiderer, C. L.; McCutchen, E.; Thacker, E. E.; Kolasa, K.; Ward, M. K.; Parsons, D.; Harrell, L. E.; Dobrunz, L. E.; McMahon, L. L. Sympathetic sprouting drives hippocampal cholinergic reinnervation that prevents loss of a muscarinic receptor-dependent long-term depression at CA3-CA1 synapses. J. Neurosci. 2006, 26 (14), 3745.

(58) Bierer, L. M.; Haroutunian, V.; Gabriel, S.; Knott, P. J.; Carlin, L. S.; Purohit, D. P.; Perl, D. P.; Schmeidler, J.; Kanof, P.; Davis, K. L. Neurochemical correlates of dementia severity in Alzheimer's disease: relative importance of the cholinergic deficits. J. Neurochem. 1995, 64 (2), 749.

(59) Moyano, P.; García, J. M.; Anadon, M. J.; Lobo, M.; García, J.; Frejo, M. T.; Sola, E.; Pelayo, A.; Pino, J. D. Manganese induced ROS and AChE variants alteration leads to SN56 basal forebrain cholinergic neuronal loss after acute and long-term treatment. Food Chem. Toxicol. 2019, 125, 583.

(60) Hudgens, E. D.; Ji, L.; Carpenter, C. D.; Petersen, S. L. The GAD2 promoter is a transcriptional target of estrogen receptor (ER) alpha and ER beta: a unifying hypothesis to explain diverse effects of estradiol. J. Neurosci. 2009, 29, 8790.

(61) Bielarczyk, H.; Jankowska, A.; Madziar, B.; Matecki, A.; Michno, A.; Szutowicz, A. Differential toxicity of nitric oxide, aluminum, and amyloid- $\beta$-peptide in SN56 cholinergic cells from mouse septum. Neurochem. Int. 2003, 42, 323.

(62) Szutowicz, A.; Bielarczyk, H.; Gul, S.; Ronowska, A.; Pawełczyk, T.; Jankowska-Kulawy, A. Phenotype-dependent susceptibility of cholinergic neuroblastoma cells to neurotoxic inputs. Metab. Brain Dis. 2006, 21, 143.

(63) Livak, K. J.; Schmittgen, T. D. Analysis of relative gene expression data using real time quantitative PCR and the 2(-Delta DeltaC(T)) method. Methods 2001, 25, 402. 